\title{
Financial Reporting in Non-listed Family Firms: Insights from Interviews with CFOs
}

\author{
Martin Glaum ${ }^{1}$
}

Received: 20 November 2018 / Accepted: 11 March 2020 / Published online: 9 April 2020

(C) The Author(s) 2020

\begin{abstract}
Analysing 20 interviews with CFOs of German non-listed family firms, I report how the firms' financial reporting is organised, who are the financial statement addressees, how the CFOs define accounting quality, whether they manage earnings, and how owner families influence reporting. I also discuss the firms' costs of reporting and disclosure. Most CFOs see the requirement to disclose financial statements as a burden. They react by disclosing statements as late as possible and by providing only the minimum content necessary. As regards accounting quality, the CFOs value formal correctness, but also sustainability, persistence, and conservative estimation of net income. Most CFOs engage in earnings management, above all to achieve a positive trend in net income, in some cases also to comply with debt covenants. The influence of the owner families differs; however, in most cases the family at least "sets the tone" for the reporting. On average, the direct costs of accounting and auditing in my sample firms amount to about $1 \%$ of revenues. According to the CFOs, public disclosure does not result in material indirect costs, and most CFOs would not change much if the requirements for reporting and disclosure were abolished. These findings add to our understanding of private firm financial reporting and suggest several directions for future research.
\end{abstract}

Keywords Family firms $\cdot$ Financial reporting $\cdot$ Public disclosure $\cdot$ Accounting quality $\cdot$ Earnings management $\cdot$ Cost of financial reporting

JEL Classifications $\mathrm{M} 40 \cdot \mathrm{M} 41 \cdot \mathrm{M} 48 \cdot \mathrm{K} 20 \cdot \mathrm{L} 20$

M. Glaum

martin.glaum@whu.edu

1 WHU-Otto Beisheim School of Management, Burgplatz 2, 56179 Vallendar, Germany 


\section{Introduction}

This paper deals with the financial reporting of non-listed German family firms. In Germany, as in other European Union countries, non-listed firms that meet certain size thresholds are legally required to prepare and disclose financial statements. Non-listed (private ${ }^{1}$ ) firms are economically very important, arguably at least as important as listed firms. ${ }^{2}$ Yet financial reporting research deals predominantly with listed firms, while we have limited knowledge of what determines the demand for and the supply of private firms' financial reporting information (Salvato and Moores 2010; Prencipe et al. 2014; Bigus and Hillebrand 2017).

This study aims to provide insights into how financial reporting information is used within non-listed family-owned firms, and in the communication between the firms and their stakeholders. More precisely, using information gathered in in-depth interviews with Chief Financial Officers (CFOs) of 20 non-listed German family firms, I investigate how the firms' financial reporting is organised; who are the addressees and what are the functions of financial reporting; how the CFOs define accounting quality and whether and how they manage earnings; and how the owner families influence the firms' financial reporting. I also discuss the costs of reporting and disclosure.

Many studies on the financial reporting of family firms are based on data for listed family firms (e.g., Wang 2006; Ali et al. 2007; Prencipe et al. 2008; Cascino et al. 2010; Achleitner et al. 2014), which arguably differ from my sample firms, which are $100 \%$ family owned. Another stream of literature examines the reporting practices of small private firms and their access to sources of financing (e.g., Allee and Yohn 2009; Collis et al. 2013; Gassen and Fülbier 2015; Lisowsky and Minnis 2016; Breuer et al. 2018). In contrast, I focus on firms that are completely privately held, but well established and large.

Furthermore, previous research is based mostly on archival studies, using large datasets and quantitative methods. Archive-based quantitative research typically examines "the average behaviour of variables in large samples" (Cooper and Morgan 2008, p. 162); it investigates relatively narrow research questions and reduces complex realities to simple models (Power and Gendron 2015). Accordingly, archival studies on the financial reporting of private firms (discussed in Sect. 3, below) have mostly focused on two issues that lend themselves to quantitative analysis: whether or when firms disclose financial statements (e.g., Minnis and Shroff 2017), and the

\footnotetext{
1 I use the terms "non-listed firms" and "private firms" synonymously. At the same time, it is important to differentiate between "private firms" and "family firms". Family firms can be completely privately held (i.e., non-listed) or listed. Furthermore, private firms can be owned and controlled not only by founders and founder families, but also by institutional investors such as private equity investors or foundations.

2 For example, there are about $3.5 \mathrm{~m}$ German firms (Statistisches Bundesamt, Unternehmensregister 2017; available at https://www.destatis.de, accessed September 2019), but only 454 German firms are listed on the regulated stock market (Deutsche Börse AG, Listed companies; available at https://www.deutscheboerse-cash-market.com/dbcm-en/instruments-statistics/statistics/listes-companies, accessed September 2019). Furthermore, it is estimated that $91 \%$ of all active firms in Germany are family controlled and $87 \%$ are family led (Stiftung Familienunternehmen 2017). Similar numbers are reported for other countries (e.g., Astrachan and Shanker 2003; Mandl 2008; Prencipe et al. 2014; Hope and Vyas 2017; Bigus and Hillebrand 2017).
} 
quality of firms' earnings, using models and metrics originally developed for listed firms, such as discretionary accruals, earnings response coefficients, and conditional conservatism (e.g., Burgstahler et al. 2006; Wang 2006; Ali et al. 2007; Hope et al. 2013). What is lacking is a more comprehensive understanding of the role of financial reporting in non-listed firms. My study intends to fill this void by examining, inter alia, the following questions: What are the key functions of financial reporting in firms that are fully controlled by a small and closely-knit group of owners? What role does financial reporting play in the interaction between the firm and its owners, and which other addressees are relevant? How do the owner families in turn influence the financial reporting, and what do reporting and disclosure cost? Given the exploratory nature of my study, I used interviews, which allow researchers to address broader questions and to generate rich and nuanced information about complex and heterogeneous phenomena. Interview-based research can disentangle intricate relationships, provide information on the context and relative importance of explanatory factors, and reveal decision-makers' deeper, underlying motivations (Graham et al. 2005; Dichev et al. 2013; Power and Gendron 2015; Malsch and Salterio 2016).

My main findings can be summarised as follows. Reporting structures and processes vary widely among the firms that make up my sample. Partly, the differences can be explained by differences in firm size, but even larger firms vary widely in the differentiation and sophistication of reporting. Of the 20 sample firms, 17 prepare their consolidated financial statements according to the German Commercial Code (Handelsgesetzbuch, HGB); only three use International Financial Reporting Standards (IFRS). The CFOs generally see few or no arguments for using IFRS, and most have never even considered doing so. All 20 firms are required to publicly disclose financial statements. Most CFOs view this requirement as a burden, and their response can be summarised with the words "as little as possible, as late as possible". According to the CFOs, the major reason for their restraint is that disclosing detailed information about profits, margins, and strategy would hurt their companies vis-à-vis competitors, customers, and suppliers.

The main addressees of financial statements are the firms' own managers, the owners, and banks; their relative importance differs with the number of owners and the firms' dependence on bank financing. According to the CFOs, the most important function of financial statements is to determine income and dividend payments. Other important functions are the monitoring of debt contracts, the remuneration of managers, and managerial decision-making. When asked about desirable characteristics of financial statements, the CFOs emphasise the precise application of accounting standards and the faithful representation of the firm's situation at the closing date, but also sustainable, persistent, and conservative estimation of net income. Most CFOs explained that they regularly manage earnings, mainly to achieve a positive trend in net income and avoid "negative surprises", in some cases also to ensure compliance with debt covenants. Preferred earnings management tools are accounting for provisions and inventories.

According to the CFOs, the owner families care strongly about their firms; they strive to keep them independent and ultimately hand them over to the next generation, in line with the stereotype of family firm owners in the literature (e.g., Gomez- 
Mejia et al. 2011). The owner families' influence on financial reporting differs. Some CFOs are family members themselves and thus directly control the reporting process. In other firms, family members within the management or the supervisory board regularly discuss financial reporting with the CFO, or the family at least "sets the tone" for the firm's financial reporting. However, there are also cases where owners are quite detached from firm management and financial reporting.

During the interviews, I asked the CFOs to provide estimates of the costs of accounting and reporting. The average estimate of the direct costs (i.e., costs for personnel, IT systems, and auditing) is about $1 \%$ of revenues; however, there are substantial differences across firms. As regards indirect, proprietary costs, all CFOs agreed that the disclosure of financial statements does not have material negative effects on competitors, customers, suppliers, or employees, because the CFOs had "learned to live with" the regulation by providing only the minimum content possible in notes and management reports and (in most cases) by disclosing statements as late as possible. When asked what, if anything, they would change in their firms' reporting if the legal reporting and disclosure requirements were dropped, most CFOs said they would not change anything material. Taken at face value, the responses suggest that the requirement to disclose financial statements imposes little, if any, incremental cost on private firms, at least within my set of sample companies.

This paper contributes to the growing literature on the financial reporting of private firms by providing qualitative insights from interviews with CFOs of large, well-established firms. Using the personal interaction with the CFOs, I was able to discuss complex and sensitive matters that would not have been amenable to archival (or survey-based) research, at least not in the same degree of detail. My interview findings partly corroborate the results of prior (quantitative) studies, but provide detail and texture. For example, my interview partners gave insights into their motivations for managing earnings and the instruments they use to achieve earnings management targets. In other cases, my findings are more nuanced than those of existing studies, thus adding new facets to our understanding of private firm financial reporting. As an example, my interviews reveal that not all private firms delay the disclosure of their financial statements. Some firms voluntarily publish their statements early and make them available in the form of annual reports, partly out of socioemotional motives. The interviews also shed light on topics not considered in the existing literature, including both direct and indirect, proprietary costs of financial reporting. The rich descriptive information provided by the interviews is interesting in its own right (Power and Gendron 2015), and it may help to generate new ideas for further research, including archival quantitative research (Dichev et al. 2013; Gephart 2004; Patton 2015).

The next section of this paper outlines the institutional background: the nature of family firms and the regulation of their financial reporting in Germany. In Sect. 3, I discuss related previous research. Sect. 4 describes the interview method and the sample and data, and Sect. 5 presents the results. Sect. 6 offers a summary and concluding remarks. 


\section{Institutional Background}

\subsection{Family Firms}

Various definitions and theoretical frameworks have been developed to differentiate family from non-family firms (Chrisman et al. 2005). One definition requires that the founder or his/her family own some minimum proportion of the firm's equity. This definition has been used especially in the finance literature (e.g., Anderson and Reeb 2003; Villalonga and Amit 2006), where the agency framework dominates the discussion. Families hold large, undiversified equity stakes and thus have strong incentives to monitor management. Moreover, often the founders or members of their families are involved in the firm's management. Hence, there is a "natural" alignment of owner and manager interests (Brunello et al. 2003), and type I agency problems, which are typical for listed firms, do not exist or are much less pronounced. However, the family members, being dominant and possibly "entrenched" in their firms, may be able to extract private benefits and thus exploit minority owners (type II agency problems; see Villalonga and Amit 2006).

According to the components-of-involvement approach, family involvementownership, control, or active leadership_defines a family firm (e.g., Chua et al. 1999; Chrisman et al. 2005; Miller et al. 2007). In contrast, proponents of the essence approach emphasise that family involvement is a necessary, but not sufficient condition for a family firm and that the "essence" of family firms consists in specific firm characteristics and behaviour. In particular, it is pointed out that families invest not only financially in "their" firms, but also emotionally, and that family firms consequently pursue both financial and non-financial goals. Important non-financial goals are to retain the family's control over the firm and ultimately hand it over to the next generation (see, e.g., Gomez-Mejia et al. 2007). These goals may dominate over financial goals (Zellweger et al. 2011).

Habbershon and Williams (1999) have coined the term "familiness" to describe the close interactions between family members and the firm, and have pointed out that these interactions can provide competitive advantages. Sirmon and Hitt (2003) similarly argue that the uniqueness of family firms arises from the integration of financial and non-financial resources that family members contribute and share with the firm (also see Zellweger et al. 2010). For example, the long-term, "patient" capital provided by the owner family helps the firm pursue long-term projects, and the family's personal financial and non-financial commitment can be thought of as "survivability capital" that supports the firm in times of crisis. The more recent literature uses the concepts of social capital (Arregle et al. 2007) and of socioemotional wealth (e.g., Gomez-Mejia et al. 2007, 2011) to emphasise the importance of the non-financial investment families have committed to, and want to preserve, in their firms.

Family firms are economically important in most countries, ${ }^{3}$ but are arguably especially so in Germany. According to the Stiftung Familienunternehmen (2017), more than $90 \%$ of all firms in Germany are family controlled, and $87 \%$ are family

\footnotetext{
3 Mandl (2008, p. 39) documents that "across Europe, about 70-80\% of enterprises are family businesses", though the data are difficult to compare across countries because of differing definitions. Astrachan and
} 
led (also see Klein 2000). In comparison to Anglo-Saxon countries, fewer firms are listed (Achleitner et al. 2011), and a high proportion of even the largest listed firms are family controlled (e.g., BMW, Volkswagen, Henkel). Furthermore, it is often argued that medium-sized industrial firms that are completely family owned, the so-called "Mittelstand", form the "backbone" or the "engine" of the German economy (Audresch and Elston 1997), and pledging support for "traditional" small and medium-sized family firms is part of the common rhetoric of German politics.

\subsection{German Legal Requirements for the Disclosure of Financial Statements}

In listed firms, a major role of financial reporting is to reduce information asymmetries between managers and shareholders and thus to mitigate conflicts of interest. In non-listed family firms, the founders or their descendants themselves manage, or at least closely control, the firms they own. In this constellation it is not clear, a priori, why financial reporting should be regulated and why public disclosure of financial statements should be mandated. Regulation does standardize reporting and thereby reduce transaction costs in the economy, and the information disclosed may improve other firms' investment decisions. However, these benefits have to be weighed against the direct and indirect costs of disclosing proprietary information (Singleton-Green 2016; Minnis and Shroff 2017).

German rules for the public disclosure of financial statements depend on firm size and on the firms' legal forms, or, in the case of groups, on the legal forms of the groups' parent companies. The German Commercial Code (Handelsgesetzbuch, $H G B$ ) requires corporations (Kapitalgesellschaften), i.e., companies with limited liability (Gesellschaft mit beschränkter Haftung, GmbH) and joint stock companies (Aktiengesellschaft, $A G$ ), to publicly disclose financial statements. ${ }^{4}$ The code defines four size categories ( $\$ 267$ and $\S 267$ a HGB), based on thresholds for revenues, total assets, and number of employees. A "large" corporation must disclose a balance sheet, an income statement and notes, as well as a management commentary ( $\$ 325$ HGB). If the corporation is the parent company of a group, it must disclose consolidated group financial statements and a group management commentary. "Mediumsized" corporations may omit or summarize certain balance sheet items and footnote details ( $\$ 327 \mathrm{HGB}$ ). ${ }^{5}$ "Small” corporations need disclose only a balance-sheet

Shanker (2003), using tax returns, estimate that family firms contribute $64 \%, 59 \%$, or $29 \%$ to GDP in the USA, depending on the definition applied. According to Björnberg et al. (2014), 80 to $90 \%$ of all firms in Southeast Asia are family owned, and 70 to $80 \%$ in India and South America. For China, because of its communist past, the proportion is lower, between 35 and $45 \%$, but it is growing fast.

4 The reporting requirements for corporations are based on the European Union's (EU) Accounting Directive and therefore hold in similar form across the EU's member states. For an overview of the reporting regulations for small and medium-sized private firms in European countries, see CNA Interpreta (2011). The EU's regulation of financial reporting originally dates back to the Fourth Directive on Financial Statements, of 1978, and the Seventh Directive on Consolidated Financial Statements, of 1983. However, more recently these directives have been replaced by the Accounting Directive 2013/34/EU, dated 26 June 2013.

5 The thresholds for "medium-sized" ("large") firms are as follows: revenues >€ 12,000,000 ( $€$ 40,000,000); total assets: $>€ 6,000,000$ ( $€ 20,000,000$ ); number of employees: $>50$ (250). A firm that meets at least two of the thresholds in two consecutive years is considered to belong to the related size category ( $\$ 267$, para $4 \mathrm{HGB}$ ). Listed firms as well as banks and insurance companies, irrespectively of their size, must always follow the reporting and auditing requirements for large corporations $(\$ 340 \mathrm{a}$ and 
and a (shortened) set of notes, and are not required to disclose an income statement. "Micro" corporations need not even disclose notes (§ 326 HGB). Furthermore, while large and medium-sized corporations must have their financial statements audited, small or micro corporations need not do so $(\$ 316 \mathrm{HGB})$.

It has been argued that the public disclosure of financial reports is a "price" companies pay for the privilege of limited liability (Singleton-Green 2016). However, in Germany not only corporations, but also sole proprietorships and private partnerships ${ }^{6}$ must disclose financial statements if they meet certain size thresholds, which are, however, much higher than those for large corporations. ${ }^{7}$

$\S 325$ para 1a HGB stipulates that firms must publicly disclose their financial statements at the latest twelve months after the balance-sheet date. ${ }^{8}$ Firms must submit the statements to the electronic "Federal Gazette" (Bundesanzeiger), an internet portal operating on behalf of the German Federal Ministry of Justice, ${ }^{9}$ where they are made publicly available in the Corporate Register (Unternehmensregister). ${ }^{10}$ Compliance is monitored by the Federal Office of Justice (Bundesamt für Justiz), a branch of the Ministry of Justice. If a firm does not submit its financial statement, it is automatically reminded and notified that if it does not comply, it faces a fine of up to $€ 25,000$. If the firm still fails to submit, the fine can be imposed multiple times, and it can be imposed in parallel on the firm and personally on its officers ( $\S$ 335 HGB).

Before the current institutional arrangement was put in place in 2007, firms were required to submit their financial statements in paper form to the commercial register of their local courts. Small and medium-sized firms had to inform the public about this submission with a note in the (paper-form) federal gazette, and large firms had to publish the entire statement in the gazette. However, with no automatic monitoring

341a HGB). Listed firms are required to disclose also a cash flow statement and a statement of changes in equity ( $\$ 264$, para $1 \mathrm{HGB})$.

6 Many German private firms choose the legal form of a GmbH \& Co KG, that is, a private limited partnership (Kommanditgesellschaft, KG) where the only fully liable person is a company with limited liability $(\mathrm{GmbH})$ and the other partners' liability is limited to the capital they provide to the company. This arrangement confers the tax advantages of a private partnership while excluding the unlimited personal liability for all natural persons (also see Klein 2000). However, with regard to financial reporting and auditing private partnerships are treated as corporations if they do not have at least one natural person with unlimited personal liability ( $\$ 264 \mathrm{a}$ HGB).

7 This requirement, which goes beyond the demands of the EU Accounting Directive, is based on the Publizitätsgesetz, a law introduced in 1969. The thresholds are as follows: revenues $>€ 130,000,000$, total assets $>€ 65,000,000$; number of employees $>5000$. A sole proprietorship or a private partnership (or a group with a parent company in the legal form of a sole proprietorship or a private partnership) that meets at least two of the thresholds in three consecutive years must publicly disclose a (consolidated group) balance sheet; however, such entities are not required to disclose income statements.

8 For listed firms the deadline is four months; see $\S 37 \mathrm{v}$ Securities Trading Act (Wertpapierhandelsgesetz).

9 The management of the federal gazette is delegated to a private publishing house. While the costs for larger corporations depend on the volume and format of the documents submitted, small and micro corporations can submit their financial statements in XML format for a flat rate of $€ 28$ (for details, see www. bundesanzeiger.de).

10 The Corporate Register is linked to the European Business Register, a network of data providers from 28 European countries; for details, see www.ebr.org. The Corporate Register must be distinguished from the commercial register (Handelsregister) for legal corporate information run by the German district courts. 
and no effective sanctions, most private firms simply chose not to comply. Empirical studies in the 1990s and early 2000s documented disclosure rates between 2.5 and $17 \%$ (for an overview, see Kaya 2010), indicating that non-compliance was the norm rather than the exception. ${ }^{11}$

\section{Related Literature}

While the financial reporting of family firms is a relatively young subject of research, it has received growing attention in recent years. In the following, I outline the main streams of research that are relevant to the present study.

One such stream of research is concerned with the disclosure choices of non-listed firms. ${ }^{12}$ The available empirical evidence suggests that most private firms, when given a choice, prefer not to disclose financial statements to the public. Minnis and Shroff (2017) report that in the USA, where disclosure is not regulated, few private firms voluntarily disclose financial statements, even among large firms. In Germany, as I note above, a large majority of private firms ignored the legal requirement for disclosure until an effective supervision mechanism was put in place in 2007 (Kaya 2010). Bernard et al. (2018) examine small and medium-sized firms' disclosures in European countries where disclosure is mandatory and find that a substantial number of firms attempt to evade the requirements by "managing" their size measures to keep them below the relevant legal thresholds. Profitability, growth, and leverage are all associated with avoidance of the size thresholds, suggesting that the avoidance is motivated by proprietary disclosure costs (Bernard 2016). Finally, Minnis and Shroff (2017) conducted an online survey of European firms with regard to the perceived benefits and costs of the public disclosure of financial statements. ${ }^{13}$ A clear majority $(62 \%)$ of the (mostly small) responding firms indicated that they would not disclose financial statements if not required by law to do so. Furthermore, about half of the respondents thought that the costs of disclosure exceeded the benefits.

A further stream of research examines the "quality" of the financial reporting of family firms, where quality is measured, inter alia, with discretionary accruals, earnings persistence, smoothing, value relevance, conditional conservatism, and earnings response coefficients (Dechow et al. 2010). Wang (2006) and Ali et al. (2007) both focus on S\&P 500 firms in the US and find that firms managed or controlled by

\footnotetext{
${ }^{11}$ The Federal Office of Justice was introduced in 2007 and started monitoring compliance with the disclosure requirement in 2008. In 2008, the office sent reminders, with a threat to impose a fine, to 419,000 firms that did not disclose their financial statements in a timely fashion. Fines were actually imposed in 32,500 cases. In more recent years (2010 to 2016), the number of reminders has been somewhat lower (between 145,000 and 195,000 p.a.), but the number of fines has increased (between 55,000 and 80,000 p.a.), indicating that unwillingness to disclose financial statements is still widespread (information supplied by the Federal Office of Justice).

${ }^{12}$ A related field of research deals with the voluntary adoption of audits by family firms. For an overview of the empirical evidence, see Vanstraelen and Schelleman (2017).

13 The questionnaire was sent via email to 473,256 firms in 34 European countries. A total of 2032 firms responded $(0.43 \%)$. The firms participating in the survey are mostly small; the average survey participating firm has $€ 1.7 \mathrm{~m}$ revenues, $€ 1.2 \mathrm{~m}$ total assets, and 18 employees.
} 
the firm's founders or their families have higher reporting quality than non-family firms. ${ }^{14}$ The authors suggest that their findings can be explained by the alignment between managers and owners in family firms. These results have since been corroborated by Tong (2008) and Jiraporn and DaDalt (2009) for US firms and by Prencipe et al. (2008) and Cascino et al. (2010) for Italian firms. In contrast, Ding et al. (2011) find that Chinese firms controlled by family owners display lower financial reporting quality than non-family firms. The authors suggest that this result can be explained by type-II agency problems (expropriation of minority shareholders), which may be more pronounced in China with its rather weak capital market supervision and investor protection.

Several studies compare the reporting quality of private firms with that of listed firms. The results of these studies are not unanimous. Burgstahler et al. (2006) compare the extent of earnings management across listed and private firms from 13 European countries and find that earnings management is more pervasive in private firms than in listed firms. ${ }^{15}$ Hope et al. (2013) look at data for US firms and, in line with Burgstahler et al. (2006), find that listed firms generally have a higher earnings quality than private firms, but not in settings where firms have incentives to manage earnings or monitoring is weak. Givoly et al. (2010) compare the earnings quality of US firms that have publicly traded equity with that of US firms that are privately held but have publicly traded debt. The former firms generally have lower earnings quality, but greater conditional conservatism, than the latter. ${ }^{16}$ In a further study, Kim and Yi (2006) examine Korean listed and private firms and find that publicly traded firms engage more intensively in earnings management than privately held firms, perhaps, the authors suggest, in order to meet the expectations of financial analysts and investors.

Stockmans et al. (2010) and Pazzaglia et al. (2013) attempt to measure the influence of socioemotional wealth on earnings quality in family firms. ${ }^{17}$ Stockmans et al. (2010) find that founder-generation Flemish family firms, and those led by their founders, have a stronger tendency to manage earnings upwards in periods with poor performance than second- or third-generation firms, or those whose CEOs belong to the second or third family generation. The authors infer that the desire to protect socioemotional investment is most pronounced among firm founders and carries less weight in later family generations. Pazzaglia et al. (2013) premise that

\footnotetext{
14 Also see Chen et al. (2008), who examine the voluntary disclosure of management forecasts among US stock-listed firms. They find that family-controlled firms are less likely to provide management forecasts than non-family firms.

15 Burgstahler et al. (2006) also find systematic country differences, with earnings management being more pervasive in countries whose legal systems are of German and French origin and in countries with weak enforcement systems.

16 Ball and Shivakumar (2005) also find for the UK that listed firms exhibit greater conditional conservatism than privately held companies.

17 Also see Gomez-Mejia et al. (2014), who develop a socioemotional wealth-oriented model of earnings management in family firms. They interpret earnings management as a "gamble" in which managers risk increased scrutiny and reputation losses in an attempt to achieve "immediate gains", and they argue that "family owners use socio-emotional wealth preservation as a reference point to evaluate the costs and benefits of the gambling" (Gomez-Mejia et al. 2014, p. 391).
} 
families feel less attached to firms they have acquired than to firms they have inherited or created themselves, and find that Italian family firms that were acquired exhibit less earnings management than non-acquired family firms.

Finally, researchers have examined whether the quality of private firms' financial reporting is linked to their access to funding or their financing costs. Most of these studies focus on small or medium-sized firms (for an overview, see Hope and Vyas 2017). Survey studies from the UK indicate that financial statements play an important role in firms' bank financing (see, for example, Collis and Jarvis 2000, 2002; Collis 2008; Collis et al. 2013). Several studies document that US firms that prepare financial statements enjoy lower debt financing costs (Allee and Yohn 2009; Hope et al. 2011; Minnis 2011). Garcia-Teruel et al. (2014) find that higher accrual quality is associated with better access to trade financing for Spanish private firms. Furthermore, recent studies by Bigus and Hillebrand (2017) and Breuer et al. (2018) suggest that better financial reporting may reduce firms' reliance on individual (house) banks and allow them to adopt more competitive forms of transactional banking with a higher number of banking relationships.

To sum up, most studies on the financial reporting of non-listed firms are based on archival research. The studies mainly focus on two areas, firms' disclosure choices and the quality of firms' earnings. Especially in the latter area, the findings are inconclusive. The differences in findings may reflect differences in methods and heterogeneity in sample firms. For example, some studies focus exclusively on family firms whereas others use data for all non-listed firms, which may include, for example, firms controlled by private equity funds. Second, some studies are based on data for listed firms that are influenced or controlled by families. However, to obtain an exchange listing, a firm's owners must accept sharing control rights and far-reaching disclosure requirements, and some would argue that such firms can therefore no longer be considered "true" family firms. Third, a part of the extant research focuses on small or medium-sized firms. The present study complements the existing literature by focusing on well-established and relatively large non-listed companies, and by presenting qualitative insights from interviews with CFOs.

\section{Method}

\subsection{Research Method}

Given the exploratory nature of my research, I decided to adopt the interview method. ${ }^{18}$ As I noted above, interviews can be used to investigate issues that are difficult or impossible to investigate with quantitative, archival research or with the survey method. They are particularly suited to address sensitive, complex and mul-

\footnotetext{
18 A growing number of studies in financial accounting (e.g., Georgiou 2018), financial statement analysis and valuation (e.g., Brown et al. 2015), auditing (e.g., Beasley et al. 2009), and tax management (e.g., Feller and Schanz 2017) have recently used qualitative research methods, and in particular the interview method. Also see Dai et al. (2019) for an overview of interview-based research in accounting in recent years.
} 
tidimensional topic areas. The method allows combining open questions that aim for a broad understanding of context with specific questions that examine subtle details (Bradburn et al. 2015; Patton 2015). The personal relationship and the trust that ideally are established in an interview situation may open up the possibility to talk about sensitive issues that would be "out of bounds" for more formal research methods (Power and Gendron 2015). Furthermore, the interviewer can also question and, where appropriate, discuss in more detail unclear or incomplete responses, thus avoiding misinterpretations (Gephart 2004; Patton 2015). Taking advantage of this flexibility, I opted for a mixture of open-ended questions and closed, survey-type questions. The "backbone" of the interviews was provided by a set of closed, survey-type questions inspired by the work of Graham et al. (2005) and Dichev et al. (2013). These questions elicited standardised responses that were easy to understand, did not require coding, and could easily be aggregated and compared, both across the interviews and with findings from previous studies. The open questions allowed for differentiated explanations and extensions, thus providing for a deep, qualitative understanding and preventing misunderstandings (Patton 2015).

Like all research methods, interviews have drawbacks. While interviews can provide rich qualitative information, the responses reflect the interviewees' personal perceptions and views. Furthermore, it is possible that interviewees may consciously or unconsciously want to give socially desirable responses or responses they think the researcher wants to hear (Bradburn et al. 2015; Patton 2015). However, I assured my interview partners strict anonymity, and I prepared and conducted the interviews with great care to avoid leading questions. Furthermore, following Bradburn et al. (2015), I purposely started the interviews with uncontroversial questions (about the organisation of the firms' accounting function) and only at later stages turned to potentially more sensitive issues such as earnings management or the role of the owner families. Finally, to the extent possible I also triangulated the interview findings with additional, publicly available information about the sample firms-for example, information from the firms' financial statements, their websites, and press reports and other publications (Malsch and Salterio 2016).

\subsection{Sample}

The main data for this study are 20 semi-structured interviews ${ }^{19}$ of CFOs from German family firms. All of the firms are completely privately held, i.e., non-listed, and all are manufacturing firms (e.g., producers of machine tools, automotive and industrial components, chemicals, food products). I purposely selected the sample firms to vary in size and in the number of owners so I could examine the effects of these factors on the firms' financial reporting. Using personal and professional

\footnotetext{
19 I decided on the number 20 for pragmatic reasons. However, towards the end of the interview series the responses of my interview partners tended to become repetitive and new, unexpected arguments or ideas rarely emerged, indicating that saturation had been achieved (Dai et al. 2019).

20 I partly followed a "snowball approach" (Malsch and Salterio 2016) — that is, I asked CFOs who participated in the survey to suggest, and to contact, other CFOs within their respective networks as further interview candidates.
} 
Table 1 Sample firms: descriptive statistics

\begin{tabular}{lcccccc}
\hline & $n$ & Mean & Median & $\begin{array}{l}\text { Std.- } \\
\text { dev. }\end{array}$ & Min & Max \\
\hline Firm size and key financial indicators & & & & & & \\
Revenues (2015, in m $€$ ) & 20 & 1612.1 & 625.1 & 2444.4 & 10 & $>5$ bn \\
Total assets (2015, in m $€$ ) & 20 & 1375.5 & 470.0 & 2078.0 & 6 & $>5$ bn \\
Employees (2015) & 20 & 10,905 & 4000 & 18,074 & 70 & $>10,000$ \\
Equity to total assets (2015, in \%) & 20 & 48.9 & 51.2 & 13.3 & 25.2 & 73.2 \\
Return on equity (2015, in \%) & 18 & 12.8 & 10.8 & 7.6 & 3.5 & 26.8 \\
Internationalisation (2015, & 20 & 61.9 & 63.5 & 28.3 & 0 & 85 \\
revenues abroad as \% of total & & & & & & \\
revenues) & & & & & & \\
Firm age and ownership structure & 20 & 91.6 & 85 & 42.6 & 21 & $>150$ \\
Firm age (in years) & 20 & 3.3 & 4 & 1.3 & 1 & 5 \\
Owner generation & 20 & 20.2 & 6 & 24.7 & 1 & $>150$ \\
Number of owners &
\end{tabular}

Note: The data come from the firms' financial statements (size and financial indicators), the interviews (owner generation, number of owners), and the firms' corporate websites (firm age). Two sample firms do not publish income statements; therefore, data on net income are not available. Median and maximum values have been simplified to prevent identification of individual firms

contacts, I identified suitable target firms and approached their CFOs,,$^{20}$ explaining the aims of the project and assuring them that they themselves and their firms would remain anonymous. The willingness to support the project was very high. Only in a few cases was an interview denied, usually with the argument that the firms had a general policy not to participate in interviews or other academic studies.

Table 1 shows that the firms in my sample tend to be large. Even the smallest has revenues of $€ 10 \mathrm{~m}$, total assets of $€ 6 \mathrm{~m}$, and 70 employees, and the largest firms have revenues and assets in excess of $€ 1$ bn and several thousand employees. The size differences have implications for disclosure. While all firms in my sample are required to disclose financial statements, the smallest firm falls just short of "medium size" and therefore is not required to disclose an income statement. In one of the other firms the parent company has the legal form of a private limited partnership (Kommanditgesellschaft, $K G$ ), with one of the owners being personally liable for the company's liabilities, so this company is also exempt from the requirement to disclose an income statement. ${ }^{21}$ As I explain in Sect. 5.2, this privilege is highly relevant to the two companies and their owners.

Table 1 further shows that the firms' median ratio of book value of equity to total assets is $51 \%$. Several CFOs explained that their firms are run effectively without bank debt, conforming to the stereotype of very conservative and independence-

\footnotetext{
${ }^{21}$ In the other 18 large firms and in the "small" firm the parent companies are incorporated either as companies with limited liabilities $(G m b H)$ or as joint stock companies $(A G, S E)$, or they are limited partnerships where the general partner is a company with limited liability $(\mathrm{GmbH} \& \mathrm{Co} . K G)$. As is explained in Sect. 2.2 above, as regards financial reporting and auditing requirements, this particular type of partnership is treated in the same way as corporations.
} 
minded family firms (Achleitner et al. 2011). Most of the firms are highly internationalised; the median percentage of revenues generated abroad is $63.5 \% .^{22}$

The firms in my sample are well established and most are quite old. The average firm age is 91.6 years; the youngest firm is 21 years old, and six are older than 100 years. Accordingly, only one of the firms is still run by its founder, while half are owned by fourth- or fifth-generation family owners. ${ }^{23}$ The number of owners varies between 1 and more than 150, with a mean of 20.2 (median: 6). The number of owners correlates with firm age (Corr: 0.71), and the firms that are more than 100 years old tend to have quite extended ownership structures, with more than 20 and in one case more than 150 owners. Half of the sample firms are at least partly managed by their founder or by members of the owner families; the other half are managed exclusively by professional executives. ${ }^{24}$

To sum up, while the sample cannot claim to be representative for (German) family firms, it does represent a certain type of German family firm: well-established, large (sometimes very large) industrial firms, often active in niche markets, technologically advanced and successful, highly internationalised, but, at the same time, conservatively financed, often located in the provinces, ${ }^{25}$ and mostly unknown to the public. Simon (1996) has coined the term "hidden champions" to describe such firms.

As regards the interview partners themselves, five are members of the owner families, the other 15 being outside managers. On average, the CFOs ${ }^{26}$ have worked

\footnotetext{
${ }^{22}$ Fourteen of the sample companies are audited by Big- 4 audit firms, while five are audited by non-Big- 4 firms. While the smallest sample firm does not have an auditor, several of the others employ more than one
} auditor, especially for their overseas subsidiaries.

${ }^{23}$ Most sample firms are controlled by the founder or his/her descendants. However, one firm is majority owned by a family that bought the controlling stake only some years ago. A second firm is managed by an individual who acquired a substantial, albeit non-controlling equity stake and now jointly controls the firm with the founder family. A third firm, still controlled by the founder family, has an institutional investor as a minority shareholder. Furthermore, in some firms the early history was volatile, with frequent ownership changes and the exit of some of the original founders. In these cases, I count the generations for the remaining, dominant owner family. Where ownership is spread across generations, I record the number of the youngest generation. For example, if the founder of a firm shares ownership with his sons and daughters, I label the firm as a second-generation family firm.

${ }^{24}$ There is no strong association between firm age and the role of non-family executives-the average age of firms led by professional executives is 98.3 , that of family-led firms is 85 , and the difference is not significant $(\mathrm{t}=0.501)$.

25 Only two of the 20 firms are domiciled in large cities (Frankfurt, Stuttgart). The other 18 are located in provincial towns and in some cases in small villages in Bavaria, Hesse, Swabia, and Westphalia.

${ }^{26}$ While for brevity I use the term CFO throughout the paper, the formal roles of the interview partners differ depending on the size and organisation of their firms. In all cases, the interview partners are the members of the companies' top management teams who are responsible for financial reporting (for a similar approach, see Dichev et al. 2013). More precisely, in companies where the parent company is a stock corporation, the interview partners are "classic" CFOs, i.e., members of the board responsible for the finance function (Finanzvorstand). In most other cases, the parent companies are corporations with limited liability $(\mathrm{GmbH})$. Here, my interview partners are mostly members of the management board (Geschäftsführer) with responsibilities similar to those of a CFO in a stock corporation. In one case, the interview partner was the managing director, similar to a CEO in a stock corporation. In two cases, the companies are led by sole owner-executives, and the interview partners, while not formally part of a management board, are the heads of the finance, accounting, and administration functions. 
for their firms for 9.5 years and been in their current function for 7.5 years. Most outside managers joined their companies directly as CFOs, with previous experience in large, listed companies (4), as auditors or tax advisors in "Big-4" audit firms (3), or as consultants (2). All have university educations: one in physics, all others in business administration. Two hold MBAs from US universities, and five have PhDs, four in business administration, one in physics. ${ }^{27}$ All 20 are male.

\subsection{Interview Design and Analysis of Data}

The interviews took place between January and November 2015. All of them were conducted in person at the firms' offices. In the days before the meetings, I sent the CFOs a list of the topics that would be covered in the interviews:

- The firm: basic information about the firm (products, markets, number of owners, etc.)

- The firm's financial reporting function: the processes of financial reporting; the use of traditional German GAAP vs. IFRS; the disclosure of financial statements.

- Addressees and functions of the firm's financial reporting: the importance of different addressees and their information demands.

- Attributes of financial reporting: desirable attributes of financial statements and key financial figures; earnings management.

- The role of the family: the families' values and motives with regard to their firms and the family's influence on financial reporting.

- Costs of financial reporting: direct and indirect costs of reporting and disclosure.

In the survey-type questions, I asked the CFOs to rate the importance of items on five-point Likert scales ranging from 1 ("unimportant") to 5 ("very important"). (When asked, I also permitted the CFOs to choose fractions of numbers, i.e., 1.5, 2.5 , etc.). The questionnaire was pre-tested with a recently retired $\mathrm{CFO}$ of a large family firm and slightly revised afterwards.

The length of the interviews varied between one hour and thirty minutes and two hours and twenty minutes; the average length was one hour and forty-nine minutes. The interviews were taped and subsequently transcribed, generating 743 pages (305,072 words) of data. I then tabulated the transcriptions by question, carefully read and analysed the tabulated text and, where appropriate, coded the content across all interview transcripts, using unique codes for responses with the same meaning (Patton 2015). All interviews were conducted in German. In what follows, I quote extensively from the interviews to exemplify typical responses or to illustrate important points and to enable the readers "to 'hear' the interviewees' voices" (Georgiou 2018, p. 1304). ${ }^{28}$ While I preserve the interviewees' anonymity, I have labelled them

\footnotetext{
27 The high percentage of PhDs is typical for top managers of large German companies. In Germany, doctoral education was traditionally not perceived solely as a training phase for future scientists, but also as a "stepping stone" for a business career. Franck and Opitz (2007) examine the career paths of the CEOs of the largest 100 companies in Germany, France, and the USA in the year 2001 and find that $58.5 \%$ of the CEOs of the German companies held doctoral degrees (France, 4.1\%; US, 5.5\%).
}

28 As Dai et al. (2019) point out, using verbatim quotations is standard practice in qualitative accounting research. As the authors explain, quotations can serve three functions. First, they can be thought of 
"CFO A", "CFO B", etc., and I use these labels consistently for quotations from the same interviewee. The translations into English are mine.

For the closed, survey-type questions I aggregated the responses, and I compare mean and median responses across key characteristics of the sample firms to allow for a systematic search for patterns and interrelations (Patton 2015). Below, I tabulate summary statistics of the CFOs' responses to the closed, survey-type questions for the full sample and separately for smaller and larger firms, classed according to the median of sales revenues. ${ }^{29}$ To assess the extent of the differences in the subsample means and medians, I also report results of $t$-tests and Mann-Whitney U-tests. However, I acknowledge that the small sample size limits the validity of the tests and that the results may therefore not generalize to larger populations of family firms.

\section{Findings}

\subsection{Organisation of the Accounting Function and Introduction of IFRS}

With the first set of questions I asked the CFOs to describe in general terms the organisational set-up and the main processes of their companies' accounting functions. The responses revealed wide heterogeneity in structures and procedures. Some of the differences are related to company size. While all sample firms are organised as groups with parent companies and subsidiaries, the smallest firm (revenues $€ 10 \mathrm{~m}$ ) is not required to prepare consolidated financial statements under the German Commercial Code and prepares only single-entity statements for the parent company and its two subsidiaries, one located in Germany, the other abroad. ${ }^{30}$ Accordingly, the firm's accounting function is relatively simple: the department consists of two parttime employees responsible for bookkeeping and cost accounting who report to the financial manager, and the firm prepares its financial statements at year-end with the help of a tax advisor.

The next biggest company, with revenues of about $€ 50 \mathrm{~m}$, has a more developed accounting function, with four employees in the parent company and an ERP system that generates monthly financial reports and quarterly consolidated financial statements. ${ }^{31}$ At the larger sample firms, the accounting functions are yet bigger

\footnotetext{
as "evidence" that researchers use to support and justify their interpretations. Second, they can be used to "elaborate"; here researchers "intermingle" direct quotes and interpretation to document the richness of their data and to produce a coherent narrative. Third, researchers may use "vivid and destabilizing accounts" from their interviews as "provocation", to challenge established ideas and beliefs. I make use of all three functions.

29 Mean (median) revenue is $€ 316 \mathrm{~m}$ ( $€ 257 \mathrm{~m}$ ) for the sub-sample of smaller firms and $€ 2.9$ bn $(€ 2.7$ bn) for the sub-sample of larger firms. Because of space limitations, I do not tabulate cross-classifications for other potential determinants of financial reporting (number of owners, owner vs. manager leadership, existence of debt covenants, etc.), but I report on important differences where appropriate.

30 All other firms prepare consolidated group statements.

31 Of the 20 sample companies, 12 routinely prepare monthly consolidated financial statements for internal purposes; three companies do this only quarterly, one half-yearly, and four companies only at the end of the fiscal year. At the latter companies, a more rudimentary monthly reporting is focused on revenues and costs and other internally defined performance figures. However, the reported numbers are not consolidated
} 
and more highly differentiated, with departments for bookkeeping and accounting, group accounting, and cost accounting and controlling. However, even the larger firms differed in accounting differentiation and sophistication. There are firms with highly standardised and stringent processes: ${ }^{: 2}$

We have introduced a financial reporting process on a monthly basis, globally in our entities, which follows a very strict schedule in SAP and which has to be completed at a certain point in time. It's based on a time schedule that is relatively tight. [CFO A]

However, in other firms the accounting processes are markedly less standardised and "fast". At one large firm, the financial year ends December 31 for most subsidiaries, but the parent company reports as of March 31. The CFO explains,

An advantage is, no one pushes us.... we can first concentrate on the financial statements of the subsidiaries. We let this run its course, then we turn our attention to the parent company statement. Then come the auditors. This is completely different to what I knew from before [at a large listed company], with "hard close" and "fast close". [CFO B]

A challenge mentioned by several CFOs is that the firms' reporting and IT systems are often heterogeneous across group companies:

You always need to take into account the kind of IT landscape you have. When I started here, each group company had its own IT system. By now, we have at least put all our European group companies on SAP. ... Our cost accounting systems also do not follow uniform principles. These are often the issues you have to contend with in the "Mittelstand". [CFO C]

German non-listed firms have the option to use IFRS or traditional German GAAP as the basis for their consolidated financial statements ( $\$ 315 \mathrm{a}$ HGB) ${ }^{33}$ For years, it has been debated whether German non-listed firms would voluntarily adopt IFRS in larger numbers and whether the government would ultimately make IFRS mandatory for their consolidated statements, and possibly for single-entity accounts. Proponents of such a development pointed to the higher information value and decision usefulness of IFRS; critics pointed to the incompatibility between fair-value accounting and the central tenet of the German accounting tradition, the prudence principle, and also to the complexity of the rules and the extensive disclosure requirements (see, for example, Küting et al. 2011; Achleitner et al. 2011).

The empirical evidence shows that most non-listed firms are reluctant to adopt IFRS voluntarily. According to Bassemir (2018) and Bassemir and Novotny-Farkas (2018), until 2011 only $12 \%$ of all German non-listed firms that prepared consoli-

(i.e., there is no elimination of group-internal transactions and profits), and the companies do not generate monthly balance sheets.

${ }^{32}$ Firms that opt for IFRS must use the "full version" of IFRS; § 315a HGB does not allow the application of the IFRS for Small and Medium Sized Entities (SMEs). On the adoption of IFRS for SMEs in other countries see, for example, Gassen (2017).

${ }^{33}$ Two of the larger firms have shared service centers for bookkeeping and other accounting functions in offshore locations. 
dated financial statements had adopted IFRS. ${ }^{34}$ In line with these studies, within my sample only three firms adopted IFRS for their external reporting. These three firms conform to two types of IFRS adopters identified by Bassemir and Novotny-Farkas (2018): large, mature firms that want to tap the public debt market, and internationally oriented "reputation seekers". Two firms have yearly revenues in excess of one billion Euros, the third more than $€ 500 \mathrm{~m}$. All three introduced IFRS more than 10 years ago. In the two very large firms, the introduction was motivated primarily by debt contracting arguments, as both use private placements in the US for their long-term debt funding. For the third firm, the introduction of IFRS was mainly motivated by reputation concerns:

We wanted to have professional standards to the outside and to the inside, and a certain, let me say, theoretical capital market readiness, even though we do not strive for a listing. As a company that is transparent and professionally led and that uses IFRS, we have a very different standing towards the capital market, towards suppliers, towards customers. We move closer to the world of our customers, the Daimlers, the Coca-Colas, and so on, who are anyway dedicated to the IFRS world, the world of transparency. And, having a level of professionalisation that conforms with international standards also helps internally, towards our owners, and to attract ambitious candidates for our supervisory board. [CFO D]

However, as the interviews revealed and as the CFOs openly conceded, at least two of the three companies actually apply IFRS with a pronounced traditional German accounting attitude - a preference for conservative measurement, relatively low levels of earnings and, thus, the accumulation of hidden reserves, and a guarded attitude towards notes disclosures. One could thus argue that the two companies are what Daske et al. (2013) call "label adopters" rather than "serious adopters" of IFRS.

The other 17 sample firms, among them four firms with annual revenues in excess of one billion Euros, continue to use German GAAP in their external reporting. ${ }^{35}$ In three cases, the firms had considered introducing IFRS in the past, but ultimately decided against such a move:

We had this discussion years ago. However, we got off it again, because one can live well with the German Commercial Code, and because we did not want to invest this much effort unnecessarily. [CFO E]

\footnotetext{
34 Also see Orens et al. (2010) for similar findings for German companies and Balsmeier and van Haverbeke (2018), who find basically the same percentage of private firms using IFRS in a large international sample from 25 countries. The latter study finds that voluntary adoption of IFRS is associated with a higher propensity to borrow from foreign banks; IFRS adoption does not appear to affect the relationship with local banks.

35 One of the 17 firms uses German GAAP for its external reporting, while applying IFRS in internal management reporting. According to the CFO, the family owners want the firm to continue disclosing German GAAP financial statements because they prefer the conservative measurement allowed under German GAAP and because they want to avoid the extensive IFRS disclosure requirements. At the same time, many of the firm's overseas subsidiaries are required to generate IFRS financial statements to fulfil local reporting requirements. Thus, the management decided it could reduce complexity and costs by introducing IFRS as the basis for its group-wide internal management reporting.
} 
We thought about it some time ago. This was several years ago, when there was this IPO boom and we thought about our strategy for the future. But we abandoned the idea again pretty quickly, both the IPO and IFRS. At the moment ... we do not see any need for it, absolutely not. [CFO F]

We considered the question of IFRS or HGB multiple times. The main reason that we gave this so much thought was actually the percentage-of-completion method, which we thought is better solved in IFRS. But in the end we always decided to stay with the German Commercial Code. [CFO G]

In the remaining companies, according to the CFOs the introduction of IFRS was not even considered. Generally, the CFOs saw few or no arguments for introducing IFRS, and they feared high costs, both immediate switching costs and recurring costs in subsequent periods. Specific arguments brought forward were that German GAAP allows for a more conservative and "flexible" measurement approach and imposes less extensive and stringent disclosure requirements. It was also pointed out that the IFRS were too complex and that some of the requirements, specifically fair value measurement, impairment testing, and capitalisation of development costs, could not be meaningfully communicated to the firms' owners, or to engineers and other staff. However, several CFOs openly conceded that they had never concerned themselves in detail with IFRS and that their knowledge of them was limited.

\subsection{Public Disclosure of Financial Statements}

All 20 companies in my sample are required by law to disclose financial statements, but as is explained above, two are not required to publish income statements. The CFOs of these two firms explained that disclosure of income statements would put an end to the high margins that their companies currently enjoyed in their respective niche markets. Furthermore, the CFO of the small company explained that he closely watches the size thresholds and would be prepared to take steps to prevent the company from hitting them (on this point, see Bernard 2016 and Breuer et al. 2019):

This is a very, very important point for us. We do everything we can to retain this size category. I may tell you, we already have a plan in our drawer should we exceed $€ 12 \mathrm{~m}$, which we strive for and which we will achieve. ... But we know how to prevent this, ... because we will never disclose our P\&L. We won't, because the competition is just waiting to see how high our margins are. [CFO H]

Most CFOs see the requirement to disclose financial statements in the Federal Gazette as a burden. There are two levers they can pull to limit the consequences of the disclosure: managing the content and managing the timing. ${ }^{36}$ As regards the content, while the format of the balance sheet and the income statement are

\footnotetext{
36 One sample company discloses only the single-entity financial statements of the group's parent company, not the consolidated financial statements, even though the company has revenues of more than $€ 250 \mathrm{~m}$ and more than 1500 employees and thus clearly meets the size thresholds that mandate the preparation and
} 
prescribed under German GAAP $(\S \S 264,275)$, the companies can influence the degree of detail in the notes and the mandatory management report. Most CFOs made it clear that they generally try to say as little as possible, and that they are particularly careful not to include information that could hurt their relationships with competitors, customers, or other contracting partners (Minnis and Schroff 2017): ${ }^{37}$

The main principle is of course minimalism because this is going to be disclosed. The auditors lean towards maximalism, which we do not like. ... The limit is where they will only just give us an unqualified audit opinion. ... Whatever comes close to confidentiality, what has the substance to be juicy for a competitor, you had better not write. [CFO I]

We say nothing. Well, no ..., of course we fulfill the requirements, for example in the notes, but we confine ourselves to what is unavoidable and what is reasonable in the competitive environment. For example, we are not interested in saying anything with regard to our research policy, to patents, the segment analysis, or to the business situation. ... We do all this in a very slim way, consciously slim. That is all very "generic". We make sure it is legally all right, ... but we look at the notes also from the point of view, could someone else use the information to hurt us. [CFO D]

Most companies fully exploit or even exceed the 12-month time period allowed by the Commercial Code.

We publish our statements only after the second admonition and the warning of a fine. [CFO F]

I think, formerly we simply refused to disclose, but then the system changed. Well, like many companies we then at first ignored the first periods and paid the fines of $€ 500$. However, at some point this becomes irritating, and the fines add up. [CFO J]

Everyone draws this out as long as possible, until you get a fine. ... We have a big competitor who is listed and I am of course always very interested in their numbers. We, however, publish our numbers always one year later. [CFO K]

Four sample companies go beyond the legal minimum disclosure through the electronic federal gazette, by having printed annual reports that are distributed among the firms' stakeholders and by making the annual reports available electronically on

publication of consolidated statements. According to the CFO, the authorities so far have not noticed the difference.

37 Several CFOs explained that they themselves use the federal gazette to obtain the financial statements of their competitors. However, other CFOs conceded that they do not do this, at least not routinely. Possible reasons for such differences may be differences in the intensity and the forms of the firms' competition (see Breuer et al. 2019). In the survey by Minnis and Schroff (2017), fewer than half of the participating firm representatives indicated that they had downloaded financial statements of competitors or customers in the past. 
their webpages. ${ }^{38}$ Three of these firms publish their reports less than two months after the end of their financial years; two even publish preliminary financial results within the first month as well as half-year figures. Of the four firms, three are among the largest in the sample, with annual revenues in excess of $€ 2$ bn and more than 10,000 employees each, and two use IFRS. As the CFOs explained, this voluntary transparency has economic and socioemotional motives. Two of the four firms are suppliers to the automobile industry, and a third produces investment goods, and the companies use the annual reports consciously to signal professionalism and solidity to their customers, to whom they are committed in the long run (Costello 2013). In two cases, the CFOs furthermore explained that the annual reports were also motivated by the personal pride of the owner families, who wanted to show friends, colleagues, competitors, and the general public how successful their companies and they themselves are, and how responsibly they use their financial wealth.

A bit of vanity is also part of it. ... And another purpose is to signal the family's social engagement. [CFO L]

The family has many contacts, relations into politics, the economy. And the annual report is a bit like their personal business card-look, what our family has achieved with the company. That is not bragging, it is simply a way to express the success the family has with its firm. [CFO M]

Still, even these four firms do not go beyond the minimum legal requirements with regard to statement content. In particular, none of the four companies publishes segment information, and all four are reserved in the notes and the management report, like the rest of the sample companies.

\subsection{Addressees of Financial Statements}

I asked the CFOs to assess, on a scale of 1 (=unimportant) to 5 (=very important), the importance of their companies' (group) financial statements for different addressees. ${ }^{39}$ Their responses are summarised in Table 2. Panel A presents the mean assessments, medians, standard deviations, and minimum and maximum values for the full sample. Panel B presents separate findings for sub-samples of smaller and larger firms.

\footnotetext{
38 The four companies also send out press releases and hold press conferences following the publication of their financial statements. Two other sample firms also organise yearly press conferences, but according to the CFOs these are primarily marketing or public relations events where they talk in general terms about the development of their companies and about revenues and investments, but never about net income.

39 With the exception of the CFO of the smallest sample firm, which does not generate consolidated statements, all CFOs agreed that their group's consolidated group financial statement was the most important statement, more important than the single-entity financial statement of the group's parent company or its tax statement. However, about half of the CFOs also considered the financial statement of the group's parent company important, because of the weight the parent company has within their groups and because this statement was the legal basis for dividend payments to the family owners. All CFOs in my sample stated that the tax statements were of only low or moderate importance to them.
} 
Table 2 The importance of financial statements for different addressees. (CFO responses to the question: "How important is the financial statement of your own firm for the following addressees?"; 5 = very important; $1=$ unimportant)

\begin{tabular}{|c|c|c|c|c|c|c|c|c|c|c|}
\hline & \multicolumn{6}{|c|}{$\begin{array}{c}\text { Panel A: } \\
\text { Full Sample }\end{array}$} & \multicolumn{4}{|c|}{$\begin{array}{c}\text { Panel B: } \\
\text { Small firms }(n=10) \\
\text { vs. large firms }(n=10)\end{array}$} \\
\hline & $n$ & Mean & & $\begin{array}{l}\text { edian Std.- } \\
\text { dev. }\end{array}$ & Min & Max & $\begin{array}{l}\text { Small } \\
\text { firms } \\
\text { (Mean) }\end{array}$ & $\begin{array}{l}\text { Large } \\
\text { firms } \\
\text { (Mean) }\end{array}$ & $t$-value & $\begin{array}{l}z \text {-value } \\
\text { (MW-U- } \\
\text { test) }\end{array}$ \\
\hline $\begin{array}{l}\text { Top manage- } \\
\text { ment }\end{array}$ & 20 & 4.23 & 5 & 1.34 & 1 & 5 & 4.30 & 4.15 & 0.24 & 0.65 \\
\hline Owners & 20 & 4.45 & 5 & 0.83 & 2 & 5 & 4.40 & 4.50 & -0.26 & -0.04 \\
\hline $\begin{array}{l}\text { Banks, other } \\
\text { lenders }\end{array}$ & 20 & 4.35 & 5 & 0.88 & 3 & 5 & 4.40 & 4.30 & 0.25 & 0.17 \\
\hline Customers & 20 & 2.43 & 2 & 1.26 & 1 & 5 & 2.25 & 2.60 & -0.61 & -1.05 \\
\hline Suppliers & 20 & 2.15 & 2 & 1.05 & 1 & 4 & 1.85 & 2.45 & -1.30 & -1.36 \\
\hline $\begin{array}{l}\text { Employees, } \\
\text { worker coun- } \\
\text { cils }\end{array}$ & 20 & 2.40 & 3 & 1.13 & 1 & 4 & 1.75 & 3.05 & $-3.10 * * *$ & $-2.59 * *$ \\
\hline $\begin{array}{l}\text { The general } \\
\text { public (local, } \\
\text { regional, } \\
\text { etc.) }\end{array}$ & 19 & 1.79 & 2 & 0.93 & 1 & 4 & 1.25 & 2.39 & $-3.31 * * *$ & $-2.61 * * *$ \\
\hline
\end{tabular}

Note: Panel A presents summary statistics for the full sample; Panel B presents mean response values separately for small and for large firms and $t$-values and $z$-values corresponding to tests for differences in means and medians based on $t$-tests and Mann-Whitney U-tests. * (**) [***] indicates that the difference is statistically significant at the $10 \%(5 \%)$ [1\%] level (two-tailed)

Three groups of addressees are clearly dominant: top management, owners, and banks (and other lenders). The other addressees_customers, suppliers, employees, and the general public - are much less important. In line with earlier studies on financial reporting in private firms (e.g., Abdel-khalik 1983; Collis and Jarvis 2000), most CFOs indicated that financial statements were very important to the group's top management because the top management teams use the numbers to steer their companies operationally and financially. Several CFOs also pointed out that evaluations of management's own performance are based on these numbers. In a few firms, financial accounting statements are less important to the management. Three CFOs responded to this item with a 2 (=not very important) and one CFO with a 1 (=unimportant), the lowest possible value. These CFOs represent companies with a clear separation of financial and management accounting, and what matters to management in these companies is primarily the internal managerial reporting. ${ }^{40}$ As one CFO explained,

\footnotetext{
40 Traditionally, financial accounting in Germany was strongly influenced by taxation (Leuz and Wuestemann 2004). Therefore, to support internal decision-making, firms developed parallel managerial accounting systems with separate performance measures. Since the 1990s, many German companies have overcome this dichotomy by introducing integrated systems where internal reporting is based on the same numbers that are reported externally. In listed companies, this "convergence" of financial and managerial accounting was driven by the introduction of international accounting standards with their emphasis
} 
The board members do not deal with the group statement directly. We always look at the internal group result at the end of the month. The external part, what kind of adjusting entries and so on take place at year-end, that does not interest us. [CFO N]

Most CFOs explained that financial statements are very important to the owner families. The mean value of 4.45 is the highest mean response in the table. Only two CFOs responded to this item with relatively low values, one with a 3, the other with a 2 . The reasons were very different. In one case the owners, which include family members as well as an institutional investor, receive monthly information packages with detailed internal managerial accounting numbers. Consequently the financial statement at the end of the financial year offers little additional information. In the other case, the founder of the company had decreed in his will that his descendants could not directly exercise their ownership rights, but would be represented by executors in the company's supervisory board and the annual shareholder meetings. Thus, family members are quite removed from all company affairs, and while they receive financial statements, according to the $\mathrm{CFO}$, they seem interested mostly in regular dividend payments, less in accounting details. In a further noteworthy case, the CFO responded to the item with a 5, but this assessment pertained only to the firm's main shareholder, who is also the CEO. The firm also has numerous minority shareholders from other family branches, who do not regularly receive (and apparently do not normally demand) income statements. According to the CFO, the reason for this information policy is the concern that it could hurt the company if income statement information were shared more widely and competitors and customers gained access to information about profits and margins.

In line with previous studies on private companies (Abdel-khalik 1983; Cascino et al. 2014; Collis and Jarvis 2000; Collis et al. 2013), the CFOs in my sample also rated banks as important addressees of financial reporting. Thirteen CFOs awarded banks the maximum value of 5 , two others a 4 . In twelve companies banks receive quarterly, in the other cases yearly financial statements, often augmented with internal reports, such as segment information or planning data. In 16 companies, banks also regularly receive the auditor's report, which under German law usually is a comprehensive and detailed discussion of the company's financial accounting and the audit findings (Leuz and Wüstemann 2004). Some of the CFOs explained that their firms currently did not actually need bank financing, and some sample firms regularly tap the bond market to avoid dependence on banks. This explains why five CFOs rated the importance of banks as addressees with only a 3. However, most of these CFOs explained that they nonetheless regularly supplied their banks with

on decision usefulness (Wagenhofer 2006; also see Weißenberger and Angelkort 2011 and Weißenberger et al. 2011). In my sample, according to the CFOs, eight companies follow an integrated approach. In two further cases, the CFOs explained that they were working towards an integrated system but had not yet completed the roll-out in all of the group companies. Nine CFOs explained that their companies followed the traditional distinction between financial and managerial reporting, and, as is mentioned above, one firm uses German GAAP (HGB) for its external reporting, while applying IFRS in its internal management reporting. 
financial statements and other information to maintain a good working relationship in case of future financing needs.

Eleven of the 20 companies have bank loans with covenants that relate to financial statement ratios. ${ }^{41}$ In three cases according to the CFOs the covenants had little or no practical relevance because the thresholds were "far away". In other cases the covenants were binding restrictions and the CFOs therefore "tracked" their firms' performance in relation to them on a monthly basis. Finally, all of the CFOs denied that banks exerted any direct influence on their firms' financial accounting. That is, according to the CFOs, the banks do not require the firms to use, or refrain from using, specific accounting policies. More generally, according to the CFOs, bank representatives never appear to question the firms' financial statement numbers.

Several CFOs also mentioned credit analysts as important addressees of their firms' financial statements, but this importance appears to be industry specific. Suppliers in the automobile industry are subject to standardised credit assessment procedures, and a company that engages in large engineering projects regularly deals with credit insurance companies. Either the credit bureaus and credit insurance companies receive the companies' financial statements, or the companies are required to fill out forms that require financial statement data (also see Cascino et al. 2014; and Hope and Vyas 2017, on the use of accounting information by debt investors and credit bureaus).

Recently, researchers have paid some attention to the importance of financial statement information for firms' contracting with customers and suppliers (e.g., Crawford et al. 2019; Hui et al. 2012). The CFOs of my sample firms generally attached only low importance to customers (mean value: 2.43 ) and suppliers (mean value: 2.15 ) as addressees, but these low averages mask high importance in individual cases. Three CFOs perceived customers as very important (=5) or important (=4). The three firms produce components for the automobile industry and for other large multinational firms and are therefore subject to regular and close scrutiny of their long-term financial stability.

According to the CFOs, financial statement information usually plays no role in the contracting with individual employees, with the possible exception of highly educated experts and members of the management: ${ }^{42}$

I have never ever met a job applicant who, before the job interview, looked up our financial statement in the federal gazette and studied our balance sheet.

[CFO O]

There are applicants who bring it up in discussions. The more senior ones do.

Not all, though, surprisingly. [CFO I]

\footnotetext{
${ }^{41}$ See Ball et al. (2008), Demerjian (2011), and Christensen and Nikolaev (2012) for discussions of the role of covenants in debt financing. Also see Shivakumar (2013).

${ }^{42}$ In the survey by Minnis and Schroff (2017), only a minority (12.2\%) of the participating firm representatives indicated that they believed that employees "definitely will" download the financial statements of their firms. The authors also surveyed members of national standard setters on this question, and a much higher proportion of this group (41.7\%) thought that employees would download their firms' financial statements.
} 
In contrast, some CFOs explained that financial statement information could be relevant in negotiations with worker councils (Betriebsrat), which, under German law, have quite far-reaching information and co-decision rights with regard to organisational and social issues, such as working hours (e.g., overtime or short-time work), supervision or monitoring of work processes, and dismissals and lay-offs of employees. As one CFO explained,

The members of the worker councils and also union representatives who are sometimes involved in discussions like to refer to our accounting numbers. ... We mustn't beat the drum too loudly, too positively, because then they will tell us, you are doing so well, you should be able to pay a special bonus to the employees. [CFO P]

The findings in Panel B of Table 2 indicate that top managers, owners, and banks are very important statement addressees both in smaller and in larger firms. However, size appears to moderate the importance of other addressees: customers, suppliers and, in particular, employees and the general public are more important for larger firms than for smaller firms. A possible explanation is that communication with stakeholders becomes more formalised with increasing firm size, rendering standardised financial statement information more important. Further untabulated analyses show that CFOs of firms with debt covenants see banks as more important addressees than CFOs of firms without debt covenants. Furthermore, in firms with larger numbers of owners, the owners themselves, as well as customers and suppliers, are more important addressees for financial statements than in firms with smaller numbers of owners. ${ }^{43}$ These findings conform with intuition. As the number of owners increases over generations, personal involvement and direct contact with company management are likely to decrease, so that the firm tends to become more similar to listed firms (e.g., Stockmans et al. 2010). Similarly, as family ownership becomes less concentrated, communication with customers and suppliers is likely to become less personal, putting more emphasis on financial statement data.

\subsection{Functions of Financial Reporting}

In the interview section on the functions of external financial reporting, I again posed a set of closed questions, following Dichev et al. (2013). Table 3 summarises the CFOs' responses.

The first two items pertain to the valuation function of financial reporting. Dichev et al. (2013) surveyed CFOs of public and private firms in the US. Almost all CFOs from public firms $(94.7 \%)$ indicated that "earnings" are very important "for use by investors in valuing the company" (importance levels 4 or 5), and $75 \%$ of the private firm CFOs shared this view. In contrast, in my interviews 19 of the 20 CFOs indicated that "valuation of firm by potential investors in capital markets" was not

\footnotetext{
43 The difference between the assessments of CFOs from firms with large and small numbers of owners is statistically significant at the $10 \%$ level for customers ( $t$-value: $1.802 ; p$-value: 0.088 ; $z$-value: 1.674 ; $p$-value: 0.094). The differences with regard to debt covenants and to owners and suppliers are not statistically significant.
} 


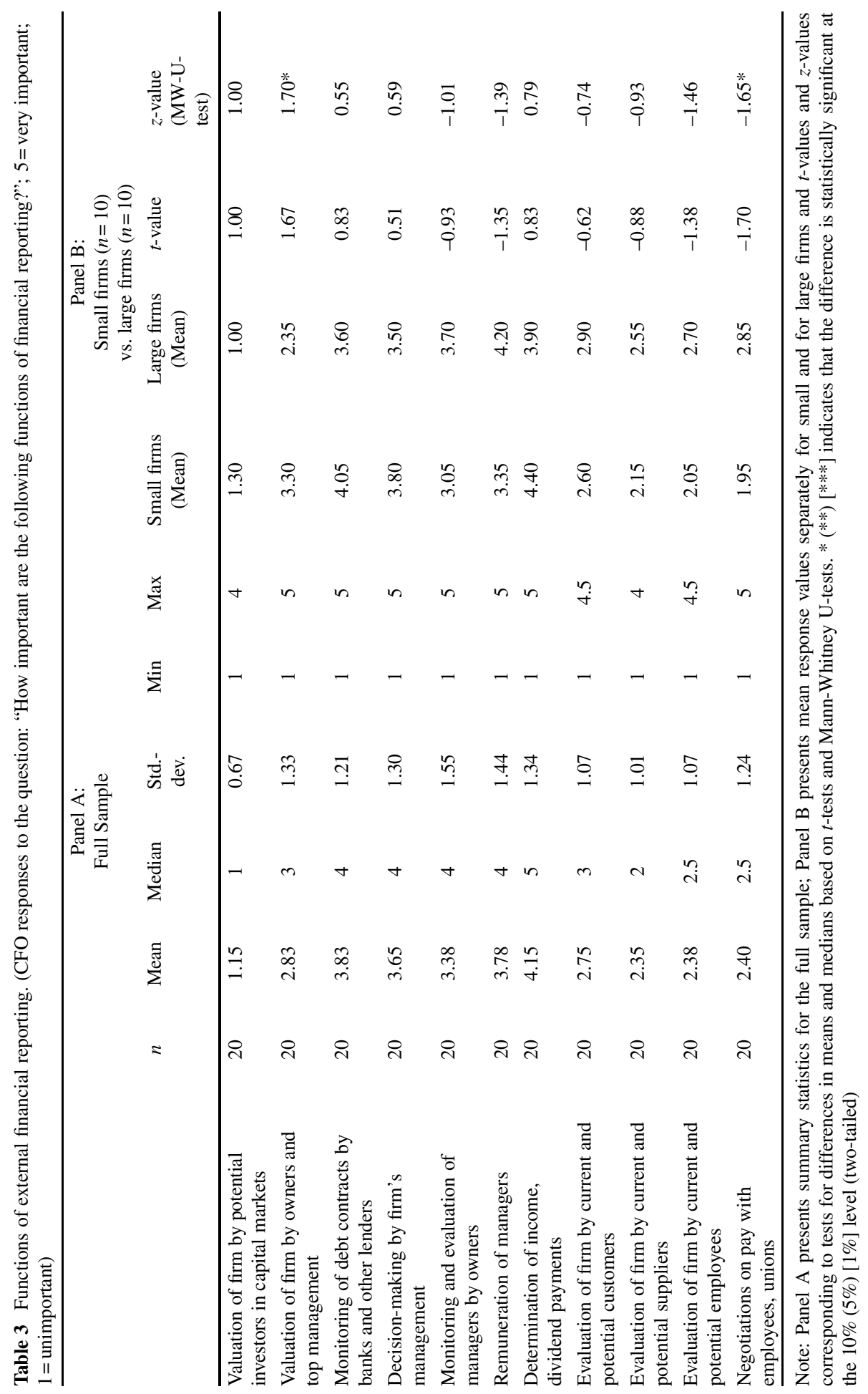


important at all ( $1=$ "unimportant"). The reason was that in almost all cases the firms' family owners have no intention to sell their firms (see Sect. 5.7 below). ${ }^{44}$ Also, some of the private firms CFOs surveyed by Dichev et al. may have been owned by private equity funds; this would explain their propensity to see valuation by investors as an important financial reporting function.

My set of closed questions also included the item "valuation of firm by owners and top management", following a suggestion I had received in the pre-testing of the questionnaire. The mean assessment of 2.83 indicates that this financial statement function has some practical relevance. In fact, seven CFOs responded to this item with a 4 or a 5 . Two CFOs explained that they regularly estimate the value of their firm to assess its performance. The other CFOs explained that they were required to perform firm valuations from time to time as a result of ownership changes, to calculate inheritance or gift taxes. ${ }^{45}$

The next item concerns the debt contracting function of financial statements. Almost $80 \%$ of the US private firm representatives surveyed by Dichev et al. (2013) considered this function very important (importance levels 4 or 5). For my sample, the mean response of 3.83 indicates that not all of the CFOs attach the same importance to it. While thirteen CFOs also responded with a 4 or 5 , seven responded with a 3,2 , or (in one case) even a 1 . In all of the latter cases, the firms had no or little bank debt and, with only one exception, no debt covenants. ${ }^{46}$

The internal, managerial decision-making function of financial statement information was rated as very important (level 4 or 5) by $85.4 \%$ of the US private firm representatives surveyed by Dichev et al. (2013). With a mean response of 3.65, the assessment in my sample is again not quite as high. A possible reason is the already mentioned strong separation of financial and management accounting that traditionally prevails in many German companies. While 13 CFOs responded to this item with a 4 or 5 , seven CFOs assigned it only a 3, a 2 , or (in one case) a 1 , and these CFOs argued that managerial decisions in their firms were based primarily on managerial accounting data, not on financial accounting data.

\footnotetext{
44 There was one exception, a CFO who responded to this item with a 4 ("important"), explaining that his firm's single owner had no children and would be prepared to sell his firm at some point if he received an attractive offer.

${ }^{45}$ Several CFOs explained that the owners of their firms were strongly concerned about inheritance tax, particularly in the light of expected changes in German inheritance tax law, and that they therefore attempted to manage the succession of ownership and the associated tax effects carefully. According to German law, interests in a firm may be largely (completely) exempt from inheritance tax if the heirs hold on to the firm and if the total sum of the firm's wages remains approximately constant over a minimum of five (seven) years. These privileges are meant to protect family-owned firms and their role in the German economy. In 2014, the German constitutional court ruled the prevailing regulations unconstitutional and mandated that parliament revise the inheritance law. In 2016, a new law was passed that still allows for a privileged inheritance of family firms, but under more stringent conditions than before. My interviews were conducted during the period of uncertainty regarding the future inheritance tax law in Germany.

46 A closer (untabulated) inspection of the responses reveals that CFOs of firms with debt covenants awarded the debt contracting function a mean importance rating of 4.45 , whereas CFOs of firms without debt covenants responded with a mean rating of 3.06; this difference is statistically significant $(t$-value $=3.117, p$-value $=0.006)$.
} 
The next items pertain to the monitoring and evaluation of the firms' managers by the owners and to the remuneration of managers. Both items are related to the stewardship or accountability function of financial reporting. The mean responses are 3.38 and 3.78, respectively, but for both items the responses varied widely. While in both cases most of the interviewees assigned either a 4 or a 5 , about a quarter assigned a 1 or a 2. Although the differences are not significant, CFOs of larger firms gave higher average ratings (3.70 and 4.20) than CFOs of smaller firms (3.05 and 3.35). A possible reason is that formalised evaluation and goal-based remuneration policies play a more pronounced role in larger companies. ${ }^{47}$ (I come back to the issue of stewardship in Sect. 5.6.).

German corporate law stipulates that companies may pay dividends to shareholders only from profits earned in the company's single-entity financial statements (Leuz and Wüstemann 2004). Against this background, it may not come as a surprise that sixteen of the twenty CFOs awarded a 4 or a 5 to the item "determination of income, dividend payments"; the mean response of 4.15 is the highest in this set of questions. Only three CFOs responded with low ratings of 1 or 2, and in these three cases the firms have fixed policies of paying constant and relatively low dividends and retaining and reinvesting the major part of net income within the firms.

The remaining four items in Table 3 pertain to the use of financial statement information in the evaluation of the firms by customers, suppliers, and employees, and in pay negotiations with employees and unions. In all four regards, the CFOs gave only relatively modest importance ratings, with means between 2.35 and 2.75 . These assessments are similar to those of the US private firm representatives surveyed by Dichev et al. (2013).

\subsection{Earnings Quality}

A broad literature deals with the "quality" of firms' earnings. However, there is no consensus on what earnings quality actually is (Dichev et al. 2013). Instead, various characteristics of earnings are discussed (persistence, smoothness, conservatism, etc.), and empirical studies often employ several measures and averages or other summary measures to assess and compare the quality of firms' financial statement information (Dechow et al. 2010; Ewert and Wagenhofer 2015). Dechow et al. (2010) emphasise that earnings quality is context dependent-that is, it depends on whether a specific aspect of earnings or, more broadly, of financial statement information is relevant to a decision in a given situation.

I presented my interview partners with a list of ten characteristics of financial reporting and asked them how important they considered them as goals for their own

\footnotetext{
47 Further, untabulated analyses indicate that these two reporting functions are more important in firms with larger numbers of owners (average responses: 3.70 and 4.15, vs. 3.05 and 3.40 in firms with lower numbers of owners) and in firms managed by non-family managers (average ratings: 3.95 and 4.40 , vs. 2.80 and 3.15 in owner-managed firms). The differences between the mean responses of CFOs from externally managed firms and those from owner-managed firms are statistically significant $(t$-values $=1.740$ and 2.115; $p$-values $=0.099$ and 0.049).
} 
firms' financial reporting. ${ }^{48}$ The CFOs' responses are summarised in Table 4 . The first two items- "representing as precisely as possible the economic events during the reporting period and the situation at the closing date" and "applying accounting standards (HGB or IFRS) as precisely as possible"-received the highest average ratings, 4.05 and 4.10. Most CFOs interpreted these two items as reflecting the formal correctness of financial reporting, with which they identified strongly. The third item focused on the transparency of financial statements and reported net income. With an average rating of 3.43, the CFOs deemed this attribute less desirable than the first two. Several CFOs pointed out that they distinguished between internal reporting (which includes reporting to owners and to the supervisory board) and the disclosure of financial statements to the public. Whereas they would aim for high transparency in internal reporting, for example, with detailed segmental information, they had no interest in being transparent in the publicly disclosed financial statements.

The CFOs furthermore expressed a preference for reporting net income figures that are sustainable and persistent (average rating: 3.85), conservative (3.73), and, to a lesser extent, smooth over time (3.43). The CFOs deemed it less important that their firms' income stream increase over time (3.08), or generate low tax payments (2.98). Finally, most CFOs did not consider high levels of revenues (2.55) or net income (2.65) to be very important, per se, in any given reporting period:

Showing high profits is really a means to an end for me, with regard to banks, to make life easy. But with regard to our competitors, I do not like to show high profits, because that could influence their pricing policy. Or customers jump off, because we have such a high margin. [CFO K]

Panel B of Table 4 further reveals differences between the responses of CFOs of smaller and larger firms. The CFOs of smaller firms reveal a stronger preference for an exact presentation of economic events and the current economic situation and for a precise application of accounting standards, while the larger firms appear to put more emphasis on sustainable and persistent, smoothened, and increasing net income and, indeed, on higher net incomes. A possible explanation is that, as firms get larger, periodic net income plays a more prominent signalling role in communication with stakeholders. ${ }^{49}$

\subsection{Earnings Management}

I also asked the CFOs whether they actively influence their firms' financial reporting numbers to achieve the desired characteristics, i.e., whether they manage earnings, and I separately addressed accounting and real earnings management activities. ${ }^{50}$

\footnotetext{
48 The list of items builds on that of Dichev et al. (2013). However, while Dichev et al. asked CFOs in the US what, in their opinion, the concept of earnings quality actually meant (an open-ended question), in my interviews I asked the CFOs to assess the importance of a given list of characteristics.

49 Further untabulated analyses did not reveal systematic univariate differences in CFO responses between CFOs of firms with larger and smaller numbers of owners, or firms that are managed by their owners and managed solely by external managers, or firms that have and do not have debt covenants.

50 A possible reason why German executives are willing to talk relatively openly about this issue is that the term Bilanzpolitik ("accounting policy") does not have the same negative connotation in Germany
} 


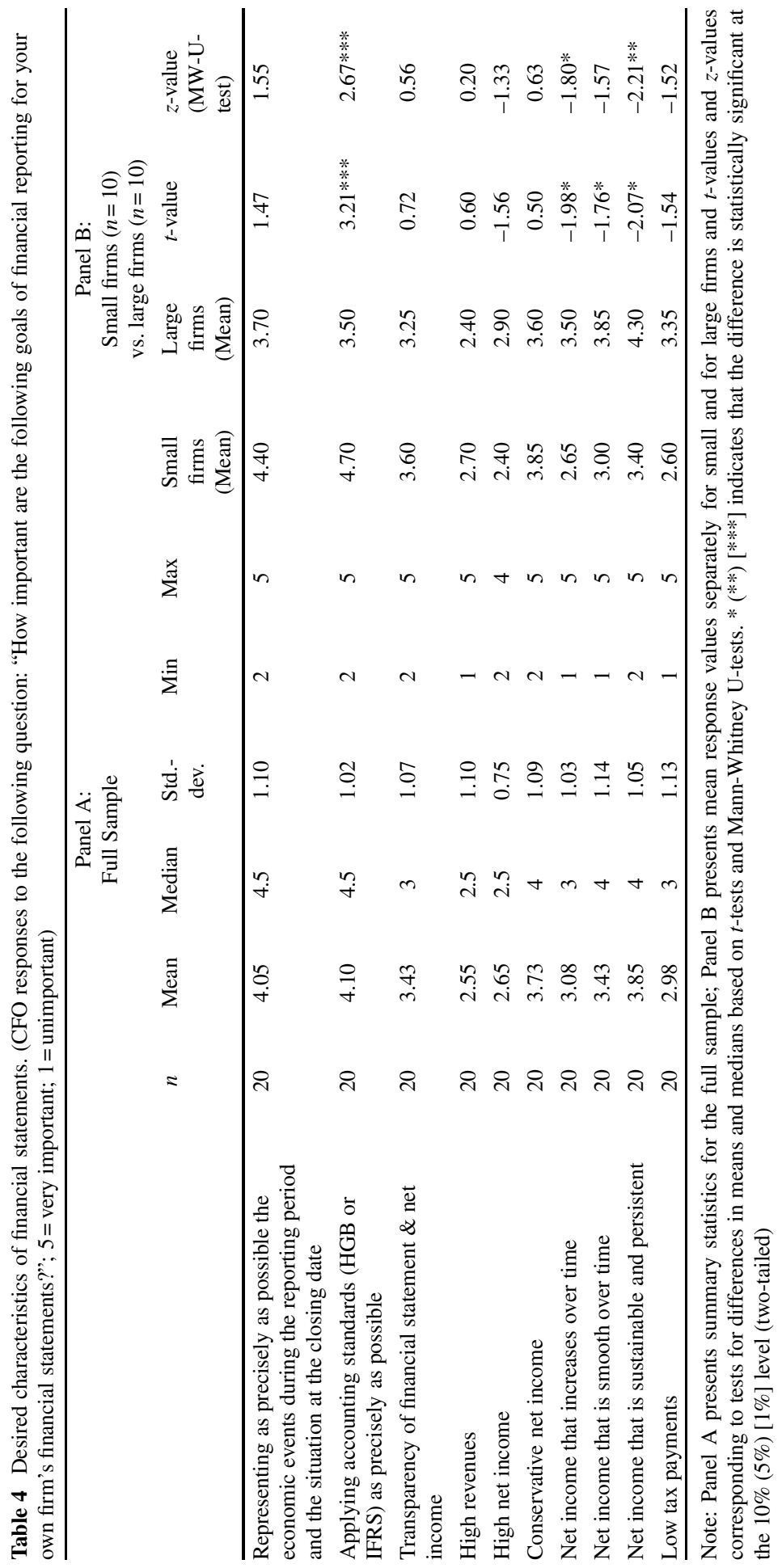


Of the 20 CFOs, only two stated that they did not manage earnings:

It has always been our philosophy in the last years: we do not engage in earnings management. [CFO G]

Managing earnings in the sense that I select methods that increase or lower net income, that is something we consciously do not do. Consistency in valuation is an immensely valuable thing for us. If you do not adhere to that, you cannot achieve transparency, hence we do not use those earnings management instruments. Full stop. That is, the numbers come out of the system and that's it. [CFO C]

One CFO did not want to give a clear answer. He was willing to talk about instruments of earnings management (see below), but emphasised that in doing so he did not admit to actually using these instruments actively.

The other 17 CFOs explained that they regularly managed the outcome of their firms' financial reporting, and that this activity was directed primarily at the firms' owners and the banks, and to a lesser extent also at customers, suppliers, the general public, and, in one case, potential investors. In all cases, the earnings management focused primarily on net income, with a mean importance rating of $4.56(n=18)$. Other potentially key financial figures were deemed markedly less important for earnings management purposes (mean importance ratings for revenues $=3.36$; cash flow from operations $=3.00$; owners' equity $=3.11$; taxable income $=3.06$ ). According to the CFOs, their earnings management aimed mainly at achieving a continuous, positive trend in their firms' net income. As was noted above, a few firms are subject to binding debt covenants that are monitored by management, and these are also targets of earnings management.

The following typical statements explain motives for earnings management:

Yes, we do. This is about an essential point, namely, showing the outside world that our business model stringently gets reflected in a continuous improvement of revenue and profit. ... We would like to show a trend to our suppliers, our customers, and potentially to possible interested parties who might perhaps want to acquire the company at some point in the future, that we are able, with our products, to increase revenue and profits continuously. [CFO $\mathrm{H}$ ]

For us it is important that a positive trend can be generated in the long run. ... That is, we want to be successful, but do not want to show profits that are too high. Continuity, stability. We are a healthy company; this is, I think, the important message that should be transmitted to the outside. [CFO N]

as its equivalent "earnings management" does in Anglo-Saxon countries (e.g., Schipper 1989; Healy and Wahlen 1999). In fact, the curriculum of German business departments traditionally comprises courses on Bilanzpolitik, and numerous text books are titled Bilanzpolitik and discuss accounting options and scope in recognition, measurement and presentation rules that can be used to manage earnings (e.g., Peemöller 1993; Tanski 2006; Hilke 2013). 
In principle, it is, let me say it like this, only about the goal to comply with the conditions of the covenants, to ensure the supply of debt financing. [CFO F]

A major concern voiced in numerous interviews was that the CFOs above all wanted to avoid "negative surprises", in particular, deviations of realised net income (and in some cases, revenue) from forecasted or budgeted figures.

Meeting the budget and the forecast—very important! Why? Credibility [in English]. Vis-à-vis banks and owners. These are the decisive factors. No surprises, please. And if there are surprises, we hopefully have so much in our pockets [i.e., hidden reserves] that we can balance them out. [CFO E]

What is important for me is reliability. I present a forecast in the middle of the year, and then again in quarter 3. When I then present a result at the end of the year that is completely different, then I have a problem. When I prepare the family for what is likely to happen, then this is fine. But when I say at year-end, I am sorry, we had planned to make a profit of $\mathrm{X}$, but now it is only half that number, that is not acceptable. [CFO M]

Interestingly, it was not only the outside managers who wanted to avoid giving the owners "negative surprises". CFOs who themselves are members of the owner families also stressed that they depended on the trust of their fellow family members who are not part of the firm's management. The following words from a familymember CFO express this feeling:

In the shareholders meeting I meet my bosses. In this situation, when I report to them, I am the manager. I am the interface, and I must also report bad news to the other shareholders. But I do not like surprises, and hence we already look at the end of the year how we can manage the result in a way so that it will still be okay next year. ... And in order to prevent surprises we sometimes have a meeting before the financial statement is completed, to report about it early. But even there you do not want a negative surprise. [CFO N]

These statements suggest that the stewardship function does play an important role in financial reporting in the firms that make up my sample, even though not all firms formally use financial statement numbers to evaluate and remunerate their managers (see above, Sect. 5.4 on the functions of financial reporting). It has been argued that conditional, news-dependent conservatism supports managerial contracting and the stewardship function of financial reporting, whereas unconditional conservatism introduces noise and makes financial statements less useful for contracting purposes (e.g., Ball and Shivakumar 2005; Shivakumar 2013). Yet the CFOs of the non-listed family firms in my sample showed a clear preference for unconditional conservatism. And instead of reporting negative news in a timely fashion, their primary motivation appeared to be to avoid negative earnings news altogether to the extent possible, by smoothing earnings over time and by "managing expectations" (also see Gassen et al. 2006, on the relationship between income smoothing and conditional conservatism).

When asked what instruments they apply to achieve their earnings management goals, eleven CFOs cited provisions for warranties, law suits, and other uncertain 
obligations, explaining that they enjoyed relatively large discretion in this regard because recognition and measurement were based on expectations and the auditors were not normally in a position to challenge their judgment. Eight CFOs referred to the measurement of inventories as a tool for earnings management. The CFO of the smallest sample firm was most outspoken on this point:

You know, as a "Mittelständler" [a medium-sized German company] we are not as SAP-ised as one of the big companies that become very transparent as a result. ... We always go very, very low, like a prudent merchant ("vorsichtiger Kaufmann"). Hence we have hidden reserves ... to fine-tune the financial statement. $80 \%$ of the Mittelständler that we know are like that. Measurement of inventory is something the Head of Accounting does himself in Excel. He takes care that it is plausible, but he never shows the true value. This is the last ace we have up the sleeve to manage earnings on a larger scale. [CFO $\mathrm{H}$ ]

Other earnings management instruments mentioned by individual CFOs were the impairment of accounts receivables; the depreciation of property, plant, and equipment (e.g., determination of economic lifetimes); the accounting for longterm construction contracts; and the recognition of low-value assets. Among the companies that apply IFRS, instruments include the accounting for development costs; the recognition and measurement of deferred taxes; and the determination of the interest rate for discounting pension provisions. While most of the practices described were rather generic and simple, others were industry specific and complex (e.g., the accounting for long-term construction contracts).

Several CFOs pointed out that German accounting law had changed over the years and does not offer as much flexibility for earnings management as in the past. However, other CFOs mentioned that the auditors and the firms' owners usually shared their general attitude and would therefore not normally question prudent accounting policies. As one CFO put it:

The best praise that we can get from the auditor when we discuss the annual financial statement in the April meeting of our supervisory board, is "the management has again presented a very conservative set of accounts". [CFO J]

Finally, I also asked the CFOs whether they engaged in real earnings management, that is, whether they would initiate changes in their firms' operations, such as accelerating or deferring investments, purchase orders, or R\&D projects, or attempting to push up sales before year-end, to achieve desired key figures or ratios in their financial statements if these could otherwise not be attained (Achleitner et al. 2014; Roychowdhury 2006). Most CFOs replied that they do in fact consider such changes when their business is not performing according to plan, but emphasised that these policies were motivated by a concern for the firms' operational goals, not primarily by financial reporting goals.

Yes, we do that. But not with regard to external reporting, but with regard to business necessities. [CFO L] 
What we do, for example, is that we step on the brakes with our investments .... Not for balance sheet reasons, we do not care about that. For cash reasons. [CFO Q]

In other cases, the concern for the firm's operational goals and financial health is coupled with incentives to meet certain financial statement key ratios. As one CFO explains,

Of course, we try to collect the cash from our receivables at the end of the fiscal year. ... We initiate a set of telephone calls, and so on and so forth. We are motivated more by the ambition to generate a little more revenue, not necessarily to "pop up" the results. However, I admit, it is also partly about syndicated loans, the covenants. We also want to reduce our gearing at the balance sheet date, this is a second aspect. [CFO O]

Moreover, some CFOs explained that they do not normally engage in real earnings management, but would resort to it in extreme situations.

That did happen during the crisis years. When we were in a really tight spot because of the slump, we did sale-and-lease-back. [CFO R]

We say, okay, we have a certain arsenal of property that is not really essential to our business, and in dire years we must sacrifice one. In such a situation, you try to generate $1,2,3$ million in income with the sale of an undervalued piece of property. [CFO J]

Finally, one firm regularly pursues real earnings management policies to manage net income downwards in years when it is unexpectedly high:

In the last five, six years, there was regularly a lot of hectic in December, when no one has time, because we noticed, wow, we will achieve a super profit, and then we ran around like headless chickens and bought this and invested in that. We sometimes asked our suppliers for invoices for things they had not yet delivered. [CFO H]

\subsection{The Role of the Family}

In an interview section on the role of the owner families, I first asked the CFOs generally about the owner families' motivations with regard to "their" firms, then specifically about the owner families' influence on firms' financial reporting. More specifically, I derived a list of possible motives of owner families from the familyfirm literature (e.g., Arregle et al. 2007; Chrisman et al. 2005; Chua et al. 1999; Gomez-Mejia et al. 2011; Prencipe et al. 2014) and asked the CFOs to indicate how important these are for their firms' owners, again using a scale of 1 (="unimportant") to 5 (="very important"). The responses must be interpreted with some caution. First, they reflect the CFOs' subjective perceptions. Some of my interview partners were well positioned to answer questions pertaining to the owner families because they were family members themselves or worked closely with family members. 


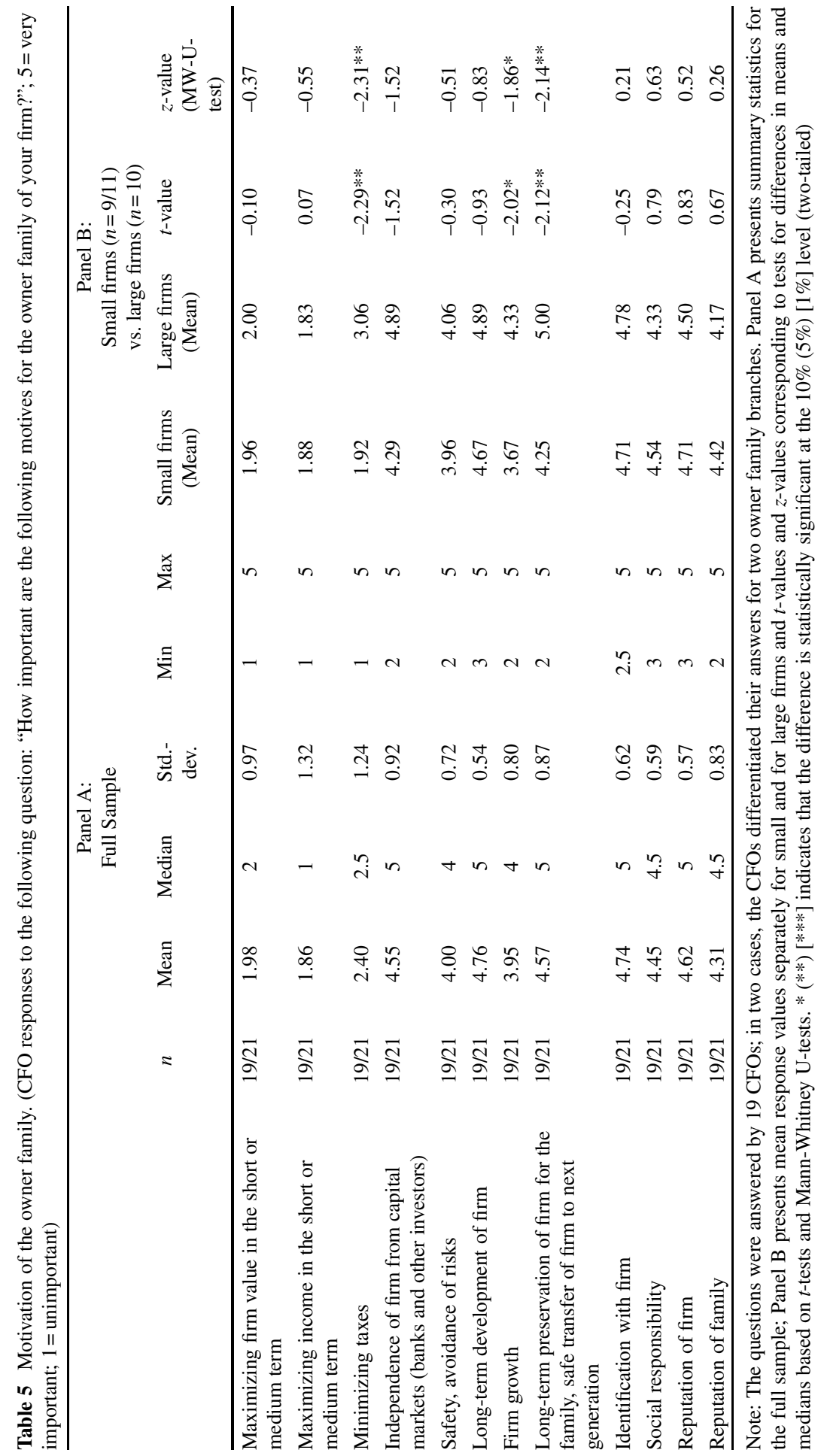


However, some CFOs had little direct contact with the owners. (One of the CFOs declined to respond to this set of questions for this reason.) Second, as has been discussed above, owner families can have numerous members, and there can be several families, with heterogeneous motivations. In fact, two CFOs differentiated in their responses between two family branches with markedly different attitudes. Thus, the summary statistics in Table 5 are based on responses from 19 CFOs, but relate to 21 families or family branches.

In general, the CFOs' responses mirror the stereotypes about family firms discussed in the literature. According to the CFOs, the owner families in my sample are generally motivated neither by short-term wealth (average importance rating: 1.98) nor by income goals (1.86), nor are they strongly motivated to minimise income taxes (2.40). Instead, they are strongly motivated to keep their firms independent from banks and other investors (4.55), to develop the firms in the long run (4.76), and to preserve and hand them over to the next generation of the family (4.57). Furthermore, the families identify strongly with their firms - the average rating of 4.74 for this item is one of the highest in this item battery-and they care about social responsibility (4.45), their own reputation (4.31), and, even more, that of their firms (4.62). ${ }^{51}$

Risk avoidance (4.00) and growth (3.95) both received moderately high importance ratings. Most CFOs stated that their owner families considered growth important, but some pointed out that growth was seen as an instrument rather than a goal in itself. Interestingly, as Panel B of Table 5 shows, the owner families of larger firms seem to attach higher weight to growth than those of smaller firms. As regards risk, some CFOs explained that the owners are aware that as entrepreneurs they need to take risks, but they would normally try to limit the risks so as to avoid "risking the firm". As one owner-CFO put it,

This is in our charter, as part of our goals, that one must only enter controllable or manageable risks-figuratively speaking, that you may only walk into the water so that you can still see your feet. [CFO I]

The second set of questions pertained to the family owners' influence on their firms' financial reporting. Not surprisingly, the responses depended to a large degree on whether, and in which function, family members were involved in the management of the company. In five of the sample companies the CFOs were family members and therefore could directly ensure that the firms' financial statements reflected the interests and motivations of the owner families. In five further companies, the CFOs were not family members, but the CEOs were. According to the CFOs, in three of these cases the CEOs were interested in financial reporting matters and regularly discussed accounting policy issues and financial statement details with their

\footnotetext{
51 As is noted in Sect. 4.1, most of the family firms in my sample are located in the German provinces. In several interviews, the CFOs mentioned that the owners themselves live in the small town or village and are part of the local community. The families have often lived in the town or village for generations, they attended the local schools (which their children or grandchildren currently attend), they are members of sports clubs, etc., all in close proximity to the employees of their firms and under the eyes of the local public. This local embeddedness, the CFOs pointed out, could partly explain the feeling of social responsibility and the strong concern about family and firm reputation.
} 
CFOs. In the other two cases, the CEOs were not trained in business administration and did not normally involve themselves in financial reporting details. One of the CFOs succinctly described his CEO's attitude:

He is not really interested in accounting details, but I believe this is also because he knows that our basic guideline is to be very conservative in our accounting and to reflect all risks. Also, when he gets to see the numbers, we present them to him at a point where things are mostly decided already. We could still go up or down 5 or 10 million, but usually, he takes the financial statements as they come out. [CFO L]

Within a firm, different family members can be involved in management and reporting processes to different degrees. For example, as was mentioned before, in one sample firm the CEO is the controlling owner and deeply involved in financial reporting matters, whereas the minority owners do not receive detailed information about the firm's financial performance. In another firm, the CFO is one of the owners, but the firm also has owners who belong to another family, who (according to the $\mathrm{CFO})$ are not much interested in accounting matters:

The only question is the dividend policy. ... How we do our accounting, and so on, that was never a question. [CFO K]

In the ten sample firms that are managed solely by external, non-family managers, the involvement of the families also varies. On one end of the spectrum are firms where family members in the supervisory board regularly discuss financial reporting with the management team. In other firms, the family does not involve itself in accounting policies or financial statement details, but "sets the tone" for the firms" general approach to financial reporting:

The basic direction is clear. There must be full trust between owners and managers. The basis for this trust is that the family knows, expects, and is informed, that our accounting policies are, as a matter of principle, conservative and cautious according to the German Commercial Code. That is enough. [CFO C]

In yet other companies the owner families are detached from the firm's management and, hence, from the financial reporting process. An extreme example is the firm mentioned above in which the founder's descendants cannot directly exercise their rights as owners but are represented in the supervisory board and in shareholder meetings by executors.

\subsection{Costs of Financial Reporting}

The question whether, and in what form, private firms should be required to disclose financial statements should rest on an assessment of the benefits and costs of alternative regulatory solutions. Leuz and Wysocki (2016) discuss the challenges involved in such an assessment. Inter alia, the authors observe (pp. 551-552) that "there is a general paucity of academic evidence that would allow us to quantify the direct costs and out-of-pocket expenses of firms" disclosure and reporting practices'. To 
Fig. 1 Direct costs of firms' reporting, as percentage of revenues

Note: The figure summarises the CFOs' estimates of the total direct costs of their firms' reporting functions (costs of personnel, information systems, and auditors, as percentage of the firms' total revenues; $n=19$ )

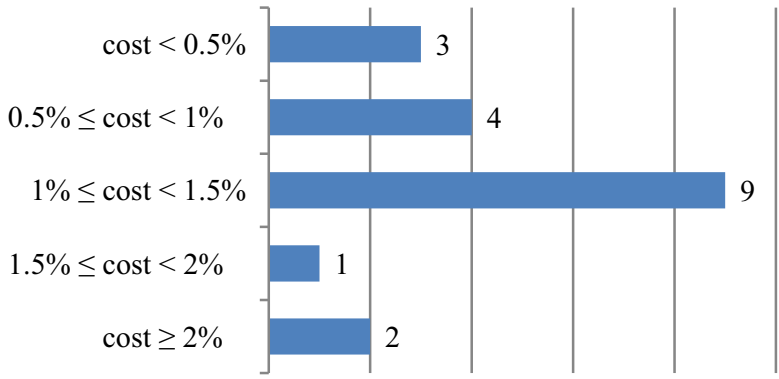

address this issue for my sample firms, I asked the CFOs for estimates of the direct and the indirect costs of reporting in their firms.

I asked the CFOs to estimate the total direct costs, i.e., costs of personnel, information systems and auditors, of their firms' reporting functions, including bookkeeping, financial accounting, and managerial accounting. To make the estimates comparable across firms, I further asked the CFOs to set the costs in relation to the firms' revenues. The mean is $1.03 \%$, but as Fig. 1 shows there are pronounced differences across firms. In three firms, the estimated cost is lower than $0.5 \%$ of revenues; however, two of these firms have relatively high revenues resulting from wholesale, trading, and commodities activities. On the other side of the spectrum, there are two cases where the estimated costs exceed $2 \%$ of revenues. One would expect that some of the costs of reporting and disclosures are fixed, so that the cost per unit of size decreases (e.g., Lang and Lundholm 1993). In line with this reasoning, I find a negative correlation between firm size (firm revenue in 2015) and percentage reporting costs, with a rank correlation of $-0.275 .{ }^{52}$

A typical cost structure for a median-sized firm in my sample, i.e., a firm with revenues of about $€ 650 \mathrm{~m}$ and 4000 employees, is as follows. The firm has about 60 full-time equivalent employees worldwide working in financial accounting and about 50 employees in managerial accounting, with average annual costs per employee of about $€ 50,000$. Hence, total personnel cost amounts to about $€ 5.5 \mathrm{~m}$. In addition, the firm incurs annual costs for IT and other administrative services of about $€ 1 \mathrm{~m}$ and auditing-related costs of about $€ 700,000$, bringing the total of accounting and reporting to about $€ 7.2 \mathrm{~m}$, or $1.1 \%$ of revenues.

The above cost estimates must be interpreted with caution. While some CFOs were ready to provide detailed cost numbers during the interviews, usually budget numbers for the relevant departments and for the auditors, others explained that their systems did not routinely record such numbers and could therefore provide only broad and sometimes rough estimates..$^{53}$ Also, the CFOs may have differed in

\footnotetext{
52 PwC recently published a "Finance Benchmarking Report 2019-20" that was based on data for 700 large companies worldwide (PwC 2019). According to this study, the median cost of the firms' finance functions (which includes the accounting function) is $0.85 \%$ of revenues. This study also documents economies of scale, with very large firms (revenues $\geq$ US $\$ 10 \mathrm{bn}$ ) having median costs of only $0.64 \%$ of revenue, while smaller firms (revenues < US \$ $1 \mathrm{bn}$ ) have median costs of $1.56 \%$ of revenue.

53 In two cases, the CFOs did not want to resort to guesswork and passed on detailed information via email after the interviews.
} 
how they defined and classified their firms' costs of reporting. One CFO declined to provide an estimate.

As for indirect costs of disclosure, as is noted above, several CFOs commented in the course of the interviews that financial statement disclosures were potentially highly relevant to their firms' competitive situations. However, when asked directly whether the disclosure harmed their relationships with competitors or their negotiations with customers, suppliers, or employees, the CFOs unanimously responded that this was not the case. As they explained further, the reason was that they had "come to an arrangement" with the current disclosure regulations, by providing only the minimum content in the notes to their financial statements and in management reports and (in most cases) by disclosing financial statements as late as possible. A sentence that came up with slight variations in several interviews was:

For the largest part, we can live with what we have to disclose today. [CFO S]

Finally, when asked what, if anything, they would change in their financial reporting functions if the legal requirements for reporting and disclosure were completely abolished, most CFOs said they would not change anything material:

Interesting question. We would still need controlling, and when I still want to have a monthly reporting system, I would not be able to save much. And as regards the auditors, we do not have them only to certify the correctness of the numbers, this also has a certain "hygiene factor", that someone has a look at everything once a year. [CFO L]

When you start with the observation that we have a separation of management and ownership and that there are more than 25 owners I have to satisfy, then I would change 0.0 . I would still have an auditor, I would certainly want to base myself on accounting principles that are generally accepted, so that I am on firm ground. That is self-preservation, very simple. [CFO C]

Four CFOs responded that without legal requirements they would stop preparing a management report. Four would reduce the volume of the note disclosures, and two did not see the need for separate cash flow statements or statements of changes in equity. Three mentioned that they would simplify the accounting for business consolidations and de-consolidations, which they found overly complicated and burdensome. One CFO of a firm that applies IFRS felt similarly about the impairment testing of goodwill; in the hypothetical situation without legal requirements he would apply a simple amortisation schedule instead. And one CFO (with an HGB background) criticised the effort required to calculate deferred taxes, which, in his opinion, held no information value.

Finally, with only one exception the CFOs indicated that they would continue to have their financial statements audited even if this were no longer mandatory. The exception, himself a member of the owner family, thought that auditor fees outweighed the benefits. A few of the other CFOs argued that audit costs could probably be reduced by doing the audits more economically. However, generally the CFOs saw a benefit in having an independent assessment and quality assurance for their financial reporting (Vanstraelen and Schelleman 2017). To conclude, if taken at 
face value, the $\mathrm{CFO}$ responses suggest that the legal requirement for private firms to generate and disclose audited financial statements imposes little, if any, incremental cost, at least within my set of sample companies.

\section{Conclusions and Perspectives for Further Research}

This paper reports the findings of a study that is based on interviews with CFOs of 20 large German non-listed family firms. Even though my sample consists entirely of family-owned manufacturing firms, the interviews revealed great diversity in reporting and disclosure practices. By construction, the sample firms differ in size, and there is a noticeable relationship between the firms' size and the development of their accounting functions. However, even among the larger firms some have parsimonious, others large and differentiated accounting functions. In some firms, financial and managerial accounting are clearly separated; others have integrated systems.

Most sample firms continue to prepare their consolidated financial statements according to German accounting standards. The firms' CFOs see few or no arguments in favour of IFRS. Most firms never even considered introducing IRFS, and several CFOs, among them CFOs of very large firms, conceded that they had no detailed knowledge about them. Only three firms use IFRS in their financial reporting, and these mostly apply IFRS with a traditional German accounting attitude: a tendency for conservative measurement, low levels of earnings and an accumulation of hidden reserves, and a guarded attitude towards notes disclosures. All three firms switched to IFRS more than 10 years ago. Hence, my (small) sample does not evince any trend to adopt IFRS.

Almost all CFOs perceive the legal requirement to disclose financial statements as a burden. However, a closer view again reveals differences. Most firms respond to the requirement by disclosing their statements as late as possible and by giving away as little information as possible. A few adopt a more extreme avoidance: the CFO of the smallest sample firm indicated his willingness to "manage" the firm's size indicators to prevent the firm from having to disclose income statements ${ }^{54}$, and the main owner of another (large) firm is willing to accept full personal liability as a "price" for avoiding income statement disclosure. In contrast, a few firms voluntarily publish their financial statements early, hold press conferences, and make annual reports, including income statements, available to the public.

The main addressees of the firms' financial statements are top management, owners, and banks, with their relative importance depending on the firms' financial situation, industry segment, and size. Some firms depend on bank financing and make detailed financial statement information available to banks, and CFOs of firms with binding debt covenants closely track their firms' performance in relation to these covenants and manage earnings to comply with them. Other firms do not currently need bank financing, but nonetheless supply their banks with financial statements in case of future financing needs. Firms that are suppliers to the automobile industry

54 The study by Bernard et al. (2018) indicates that this attitude is quite widespread among private firms. 
or to other large, dominant firms also make detailed financial statement information available to their customers and to credit analysts who work on behalf of the customers. Finally, my findings indicate that in larger firms and in firms with larger numbers of owners, as communication with stakeholders becomes more formalised, financial statements also become more important for other addressees, customers, suppliers, employees, and the general public.

According to the CFOs, the most important function of financial statements is to determine income and dividend payments. The monitoring of debt contracts, managerial remuneration, and supporting firm-internal decision-making are also important. Most CFOs highly value the formal correctness of financial statements, but also sustainability, persistence, and conservative estimation of net income. Most firms regularly manage earnings, in particular to achieve a continuous, positive trend in net income and in some cases also to ensure compliance with debt covenants.

According to the CFOs, the firms' owners identify with their firms, care about reputation, strive for independence, and aim to ultimately hand over their firms to the next generation. The families' involvement in financial reporting varies widely. In cases where the CFOs themselves are family members, they directly control the reporting process. In most other firms, family members within the management or the supervisory board regularly discuss financial reporting with the CFO, and in almost all cases the family at least "sets the tone" for the firm's reporting. However, in exceptional cases family owners are not at all involved in financial reporting.

Finally, the (direct) costs of reporting and disclosure in my sample firms, i.e., the costs for personnel in bookkeeping and financial and managerial reporting, and for IT systems and auditing, on average amounted to about $1 \%$ of total revenues. According to the CFOs, the firms do not suffer material indirect, proprietary costs of public disclosure, and most CFOs said they would not implement substantial changes if the legal requirements for reporting and disclosure were abolished.

These findings suggest several directions for future research. First, future research could investigate more deeply why private firms adopt such disparate reporting and disclosure practices. For example, my findings suggest that a mixture of socioemotional and economic factors explain the different approaches to disclosure and transparency. The early disclosure of financial statements, the voluntary disclosure of annual reports, and the press conferences in some of the transparent firms were motivated, inter alia, by a desire of the owner families to showcase their commercial success and their social engagement. As regards economic factors, the transparent firms in my sample enjoy strong competitive positions that are protected by superior technology or marketing prowess, whereas the highly secretive sample firms appeared to be extraordinarily profitable, within niche markets that are not protected by high barriers to entry. ${ }^{55}$

A second area for further research could be the (non-) adoption of IFRS by private firms. A majority of my sample firms, among them some of the largest firms, had never considered adopting IFRS, and several CFOs had no detailed knowledge of IFRS. Against this background, it could be interesting to examine more broadly

\footnotetext{
55 Also see Li (2010), Cheng et al. (2013), and Ali et al. (2014) for studies on the relationship between product market competition and reporting and disclosure quality (in the context of listed firms).
} 
how managers in private firms perceive, evaluate, and decide on financial reporting policy choices. A further question in this context relates to firms that do adopt IFRS, but then continue to account and report in the German tradition, with conservative measurements and guarded disclosures. It would be interesting to find out whether this mere "label adoption" (Daske et al. 2013) is widespread among private firms and whether the firms gain anything from the label adoption.

A third area where future research could be fruitful is the earnings management of private, family-owned firms. Within my sample, earnings management was common. However, my sample firms are completely privately held, and the managers and the owners themselves are major addressees of financial statements (and several of the firms did not require bank financing), so one might ask whom the CFOs are "fooling" with their earnings management. A related topic that could be explored further is the clear preference of the CFOs of my sample firms for unconditional conservatism. This attitude is in contrast to the widely held view in the literature that conditional conservatism supports the contracting and stewardship function of financial reporting information, whereas unconditional conservatism, according to Ball and Shivakumar (2005, p. 91), "can only reduce contracting efficiency". Furthermore, none of the CFOs appeared to perceive a discrepancy between their high regard for formal correctness of financial reporting on the one hand and their widespread earnings management on the other hand, and it could be interesting to examine more deeply how the CFOs reconcile and justify these seemingly contradictory positions.

Also, studies could examine more closely the assertion that structures in family firms are not as formalised and rigid as in listed firms (James 1999; Stewart and Hitt 2012). Finally, during the interviews I observed that financial reporting in numerous sample firms had undergone significant changes in recent years-for example, to integrate external and internal reporting, to replace outdated IT systems, and to introduce harmonised ledgers and standardised processes. Such changes often followed changes in the CFO position, in particular the hiring of outside experts, and in several cases such hires appeared to have resulted from severe crises. More generally, my interviews left me with the impression that the accounting structures and processes in family firms depend quite strongly on the individual CFO, on his ${ }^{56}$ preferences, and on whether he previously worked in financial accounting or controlling, or in a listed company or an audit firm. Thus, as a specific application of the "upper echelon theory" (Hambrick and Mason 1984; Plöckinger et al. 2016), it could be fruitful for further research to explore more deeply the human factor in the financial reporting of family firms - that is, the influence of top managers and owners' values and other personal characteristics.

Acknowledgements I am very grateful to the CFOs of the German family firms who agreed to be interviewed for this research. I am deeply indebted to Harald Völker, who helped in the development of the questionnaire and provided valuable feedback to earlier versions of the paper. I thank two anonymous reviewers and the editor, Alfred Wagenhofer, for constructive comments. I also thank Nadine Kammerlander, Franz Kellermanns, Max Leitterstorf, and Thorsten Sellhorn as well as workshop participants at the University of Lausanne, Université Toulouse Capitole, Henley Business School at the University of Reading, and Universität Regensburg for helpful comments on earlier versions of the paper. Finally, I gratefully acknowledge financial support for this project from the Ernst \& Young Stiftung (Ernst \& Young Foundation).

56 As is mentioned in Sect. 4.1, all CFOs in my sample are male. 
Funding Open Access funding provided by Projekt DEAL.

Open Access This article is licensed under a Creative Commons Attribution 4.0 International License, which permits use, sharing, adaptation, distribution and reproduction in any medium or format, as long as you give appropriate credit to the original author(s) and the source, provide a link to the Creative Commons licence, and indicate if changes were made. The images or other third party material in this article are included in the article's Creative Commons licence, unless indicated otherwise in a credit line to the material. If material is not included in the article's Creative Commons licence and your intended use is not permitted by statutory regulation or exceeds the permitted use, you will need to obtain permission directly from the copyright holder. To view a copy of this licence, visit http://creativecommons.org/licenses/by/4. $0 \%$

\section{References}

Abdel-khalik, A. 1983. Financial reporting by private companies. Research Report, Financial Accounting Standards Board. Stamford: Conn.

Achleitner, A., C. Kaserer, N. Günther, and S. Volk. 2011. Die Kapitalmarktfähigkeit von Familienunternehmen [Capital market access of family firms]. München: Studie für die Stiftung Familienunternehmen.

Achleitner, A.K., N. Fichtl, C. Kaserer, and G. Siciliano. 2014. Real earnings management and accrualbased earnings management in family firms. European Accounting Review 23(3):431-461.

Ali, A., T.Y. Chen, and S. Radhakrishnan. 2007. Corporate disclosures by family firms. Journal of Accounting and Economics 44:238-286.

Ali, A., S. Klasa, and P.E. Yeung. 2014. Industry concentration and corporate disclosure policy. Journal of Accounting and Economics 58(2-3):240-264.

Allee, K.D., and T.L. Yohn. 2009. The demand for financial statements in an unregulated environment: An examination of the production and use of financial statements by privately held small businesses. Accounting Review 84(1):1-25.

Anderson, R.C., and D.M. Reeb. 2003. Founding-family ownership and firm performance: evidence from the S\&P 500. Journal of Finance 58:1301-1328.

Arregle, J.-L., M.A. Hitt, D.G. Sirmon, and P. Very. 2007. The development of organizational social capital: attributes of family firms. Journal of Management 44(1):73-95.

Astrachan, J.H., and M.C. Shanker. 2003. Family businesses' contribution to the U.S. economy: a closer look. Family Business Review 16(3):211-219.

Audresch, D.B., and J.A. Elston. 1997. Financing the German Mittelstand. Small Business Economics 9:97-110.

Ball, R., and L. Shivakumar. 2005. Earnings quality in UK private firms: comparative loss recognition timeliness. Journal of Accounting and Economics 39:83-128.

Ball, R., A. Robin, and G. Sadky. 2008. Is financial reporting shaped by equity markets or by debt markets? An international study of timeliness and conservatism. Review of Accounting Studies 13(2-3):168-205.

Balsmeier, B., and S. Vanhaverbeke. 2018. International financial reporting standards and private firms' access to bank loans. European Accounting Review 27(1):75-104.

Bassemir, M. 2018. Why do private firms adopt IFRS? Accounting and Business Research 48(3):237-263.

Bassemir, M., and Z. Novotny-Farkas. 2018. IFRS adoption, reporting incentives, and financial reporting quality in private firms. Journal of Business Finance \& Accounting 45(7-8):759-796.

Beasley, M.S., J.V. Carcello, D.R. Hermanson, and T.L. Neal. 2009. The audit committee oversight process. Contemporary Research 26(1):65-122.

Bernard, D. 2016. Is the risk of product market predation a cost of disclosure? Journal of Accounting and Economics 62:305-325.

Bernard, D., D. Burgstahler, and D. Kaya. 2018. Size management by European private firms to avoid disclosure and audit costs. Journal of Accounting and Economics 66(1):94-122.

Bigus, J., and C. Hillebrand. 2017. Bank relationships and private firms' financial reporting quality. European Accounting Review 26(2):379-409.

Björnberg, A., H.-P. Elstrodt, and V. Pandit. 2014. The family-business factor in emerging markets. McKinsey Quarterly. https:/www.mckinsey.com/featured-insights/winning-in-emerging-markets/ the-family-business-factor-in-emerging-markets. Accessed 5 Mar 2020. 
Bradburn, N.M., S. Sudman, and B. Wansink. 2015. Asking questions: The definitive guide to questionnaire design-For market research, political polls, and social and health questionnaires. Hoboken: Wiley.

Breuer, M., K. Hombach, and M.A. Müller. 2018. How does financial reporting regulation affect firms' banking? Review of Financial Studies 31(4):1265-1297.

Breuer, M., K. Hombach, and M.A. Müller. 2019. The economics of firms' public disclosure: theory and evidence. Working Paper, retrieved from SSRN. https://ssrn.com/abstract=3037002. Accessed 5 Mar 2020.

Brown, L.D., A.C. Call, M.C. Clement, and N.Y. Sharp. 2015. Inside the "black box" of sell-side financial analysts. Journal of Accounting Research 53(1):1-47.

Brunello, G., C. Gaziano, and B.M. Parigi. 2003. CEO-turnover in insider dominated boards: the Italian case. Journal of Banking and Finance 27:1027-1051.

Burgstahler, D., L. Hail, and C. Leuz. 2006. The importance of reporting incentives: Earnings management in European private and public firms. Accounting Review 81:983-1016.

Cascino, S., M. Clatworthy, B. García Osma, J. Gassen, S. Imam, and T. Jeanjean. 2014. Who uses financial reports and for what purpose? Evidence from capital providers. Accounting in Europe 11(2):185-209.

Cascino, S., A. Pugliese, D. Mussolino, and C. Sansone. 2010. The influence of family ownership on the quality of accounting information. Family Business Review 23:246-265.

Chen, S., X. Chen, and Q. Cheng. 2008. Do family firms provide more or less voluntary disclosure? Journal of Accounting Research 46:499-536.

Cheng, S., P. Man, and H.Y. Cheong. 2013. The impact of product market competition on earnings quality. Accounting and Finance 53:137-162.

Chrisman, J.J., J.H. Chua, and P. Sharma. 2005. Trends and directions in the development of a strategic management theory of the family firm. Entrepreneurship Theory and Practice 29:555-575.

Christensen, H.B., and V.V. Nikolaev. 2012. Capital versus performance covenants in debt contracts. Journal of Accounting Research 50(1):75-116.

Chua, J.H., J.J. Chrisman, and P. Sharma. 1999. Defining the family business by behaviour. Entrepreneurship Theory and Practice 23(4):19-39.

Collis, J. 2008. Directors' views on accounting and auditing requirements for SMEs. London: UK Department for Business Enterprise and Regulatory Reform.

Collis, J., and R. Jarvis. 2000. How owner-managers use accounts. Research report. London: ICAEW.

Collis, J., and R. Jarvis. 2002. Financial information and management of small private companies. Journal of Small Business and Enterprise Development 9:100-110.

Collis, J., R. Jarvis, and M. Page. 2013. SMes, financial reporting and trade credit: an international study. ACCA Research Report No. 33. London: ACCA.

Cooper, D.J., and W. Morgan. 2008. Case study research in accounting. Accounting Horizons 22(2): 159-178.

Costello, A.M. 2013. Mitigating incentive conflicts in inter-firm relationships: evidence from long-term supply contracts. Journal of Accounting and Economics 56:19-39.

Crawford, S., Y. Huang, N. Li, and Z. Yang. 2019. Customer concentration and public disclosure: evidence from management earnings and sales forecasts. Contemporary Accounting Research https://doi.org/ 10.1111/1911-3846.12526.

Dai, N.T., C. Free, and Y. Gendron. 2019. Interview-based research in accounting 2000-2014: a review. Management Accounting Research 42(1):26-38.

Daske, H., L. Hail, C. Leuz, and R. Verdi. 2013. Adopting a label: heterogeneity in the economic consequences around IAS/IFRS adoptions. Journal of Accounting Research 51(3):495-547.

Dechow, P.M., W. Ge, and C. Schrand. 2010. Understanding earnings quality: a review of the proxies, their determinants and their consequences. Journal of Accounting and Economics 50:344-401.

Demerjian, P.R. 2011. Accounting standards and debt covenants: has the "balance sheet approach" led to a decline in the use of balance sheet covenants? Journal of Accounting and Economics 52(2-3):178-202.

Dichev, I.D., J.R. Graham, C.R. Harvey, and S. Rajgopal. 2013. Earnings quality: Evidence from the field. Journal of Accounting and Economics 56:1-33.

Ding, S., B. Qu, and Z. Zhuang. 2011. Accounting properties of Chinese family firms. Journal of Accounting, Auditing \& Finance 26:623-640.

Ewert, R., and A. Wagenhofer. 2015. Economic relations among earnings quality measures. Abacus 51(3):311-355.

Feller, A., and D. Schanz. 2017. The three hurdles of tax planning: how business context, aims of tax planning, and tax manager power affect tax expense. Contemporary Accounting Research 34(1):494-524. 
Franck, E., and C. Opitz. 2007. The singularity of the German doctorate as a signal for managerial talent: causes, consequences and future developments. Management Revue 18(2):220-241.

Garcia-Teruel, P.J., P. Martinez-Solano, and J.P. Sanchez-Ballesta. 2014. Supplier financing and earnings quality. Journal of Business Finance and Accounting 41(9-10):1193-1211.

Gassen, J. 2017. The effect of IFRS for SMes on the financial reporting environment of private firms: an exploratory interview study. Accounting and Business Research 47(5):540-563.

Gassen, J., and R.U. Fülbier. 2015. Do creditors prefer smooth earnings? Evidence from European private firms. Journal of International Accounting Research 14(2):151-180.

Gassen, J., R.U. Fülbier, and T. Sellhorn. 2006. International differences in conditional conservatism-the role of unconditional conservatism and income smoothing. European Accounting Review 15(4): $527-564$.

Georgiou, O. 2018. The worth of fair value accounting: dissonance between users and standard setters. Contemporary Accounting Research 35(3):1297-1331.

Gephart, R.P. 2004. Qualitative research and the Academy of Management Journal. Academy of Management Journal 47:454-462.

Givoly, D., C.K. Hayn, and S.P. Katz. 2010. Does public ownership of equity improve earnings quality? Accounting Review 85(1):195-225.

Gomez-Mejia, L., C. Cruz, P. Berrone, and J. de Castro. 2011. The bind that ties: Socio-emotional wealth preservation in family firms. Academy of Management Annals 5:653-707.

Gomez-Mejia, L., C. Cruz, and C. Imperatore. 2014. Financial reporting and the protection of socioemotional wealth in family-controlled firms. European Accounting Review 23(3):387-402.

Gomez-Mejia, L., K. Haynes, M. Nunez-Nickel, K. Jacobson, and J. Moyano-Fuentes. 2007. Socioemotional wealth and business risks in family-controlled firms: Evidence from Spanish olive oil mills. Administrative Science Quarterly 52:106-137.

Graham, J.R., C.R. Harvey, and S. Rajgopal. 2005. The economic implications of corporate financial reporting. Journal of Accounting and Economics 40:3-73.

Habbershon, T.G., and M.L. Williams. 1999. A resource-based framework for assessing the strategic advantages of family firms. Family Business Review 12:1-25.

Hambrick, D.C., and P.A. Mason. 1984. Upper echelons: the organization as a reflection of its top managers. Academy of Management Review 9(2):193-206.

Healy, P.M., and J.M. Wahlen. 1999. A review of the earnings management literature and its implications for standard setting. Accounting Horizons 13(4):365-383.

Hilke, W. 2013. Bilanzpolitik, 3rd edn., Berlin: Springer.

Hope, O.-K., and D. Vyas. 2017. Private company finance and financial reporting. Accounting and Business Research 47(5):506-537.

Hope, O.-K., W.B. Thomas, and D. Vyas. 2011. Financial credibility, ownership, and financing constraints in private firms. Journal of International Business Studies 42:935-957.

Hope, O.-K., W.B. Thomas, and D. Vyas. 2013. Financial reporting quality of U.S. private and public firms. Accounting Review 88:1715-1742.

Hui, K.W., S. Klasa, and P.E. Yeung. 2012. Corporate suppliers and customers and accounting conservatism. Journal of Accounting and Economics 53:115-135.

Interpreta, C.N.A. 2011. Study on accounting requirements for SMEs. Final report, prepared for the EU Competitiveness and Innovation Framework Programme. https://ec.europa.eu/growth/content/studyaccounting-requirements-smes-0_en. Accessed 5 Mar 2020.

James, H.S. 1999. What can the family contribute to business? Examining contractual relationships. Family Business Review 12(1):61-71.

Jiraporn, P., and P. DaDalt. 2009. Does founding family control affect earnings management? Applied Economics Letters 16(2):113-119.

Kaya, D. 2010. Strategien zur Vermeidung der Jahresabschlusspublizität [Strategies of financial statement disclosure avoidance. Doctoral dissertation. Erlangen: University of Erlangen-Nürnberg.

Kim, J.B., and C.H. Yi. 2006. Ownership structure, business group affiliation, listing status, and earnings management: evidence from Korea. Contemporary Accounting Research 23:427-464.

Klein, S.B. 2000. Family businesses in Germany: significance and structure. Family Business Review 13:157-181.

Küting, K., N. Pfitzer, and C.-P. Weber. 2011. IFRS oder HGB? Systemvergleich und Beurteilung. Stuttgart: Schäffer-Poeschel.

Lang, M.H., and R. Lundholm. 1993. Cross-sectional determinants of analyst ratings of corporate disclosure. Journal of Accounting Research 31(2):246-271. 
Leuz, C., and J. Wuestemann. 2004. The role of accounting in the German financial system. In The German financial system, ed. In J.P. Krahnen, R.H. Schmidt, 450-481. Oxford: Oxford University Press.

Leuz, C., and P.D. Wysocki. 2016. The economics of disclosure and financial reporting regulation: evidence and suggestions for future research. Journal of Accounting Research 54(2):525-622.

$\mathrm{Li}, \mathrm{X}$. 2010. The impacts of product market competition on the quantity and quality of voluntary disclosures. Review of Accounting Studies 15(3):663-711.

Lisowsky, P., and M. Minnis. 2016. Accounting choices and capital allocation: evidence from large private U.S. firms. Working paper. Chicago, Illinois: University of Chicago and University of Illinois.

Malsch, B., and S.E. Salterio. 2016. Doing good field research: assessing the quality of audit field research. Auditing: A Journal of Practice \& Theory 35(1):1-22.

Mandl, I. 2008. Overview of family business relevant issues. Study conducted on behalf of the European Commission. Brussels.: Enterprise and Industry Directorate-General.

Miller, D., I. Le Breton-Miller, R.H. Lester, and A.A. Cannella Jr.. 2007. Are family firms really superior performers? Journal of Corporate Finance 13(5):829-858.

Minnis, M. 2011. The value of financial statement verification in debt financing: evidence from private U.S. firms. Journal of Accounting Research 49(2):457-506.

Minnis, M., and N. Shroff. 2017. Why regulate private firm disclosure and auditing? Accounting and Business Research 47(5):473-502.

Orens, R., A. Renders, and K. Crabbe. 2010. Voluntary adoption of International Financial Reporting Standards in private firms: the German case. Stirling. Working paper, Eufin 2010: Workshop on European Financial Reporting.

Patton, M.Q. 2015. Qualitative research and evaluation methods: Integrating theory and practice, 4th edn., Thousand Oaks: SAGE.

Pazzaglia, F., S. Mengoli, and E. Sapienza. 2013. Earnings quality in acquired and nonacquired family firms: a socioemotional wealth perspective. Family Business Review 26(4):374-386.

Peemöller, V.H. 1993. Bilanzanalyse und Bilanzpolitik. Wiesbaden: Gabler.

Plöckinger, M., E. Aschauer, M.R.W. Hiebl, and R. Rohatschek. 2016. The influence of individual executives on corporate financial reporting: a review and outlook from the perspective of upper echelons theory. Journal of Accounting Literature 37:55-75.

Power, M.K., and Y. Gendron. 2015. Qualitative research in auditing: a methodological roadmap. Auditing: A Journal of Practice \& Theory 34(2):147-165.

Prencipe, A., S. Bar-Yosef, and H.C. Dekker. 2014. Accounting research in family firms: theoretical and empirical challenges. European Accounting Review 23(3):361-385.

Prencipe, A., G. Markarian, and L. Pozza. 2008. Earnings management in family firms: evidence from R\&D cost capitalization in Italy. Family Business Review 21:71-88.

PwC. 2019. The PwC finance benchmarking report 2019-20. https://www.pwc.co.uk/finance/financematters/insights/uk-finance-effectiveness-benchmarking-report.html. Accessed 5 Mar 2020.

Roychowdhury, S. 2006. Earnings management through real activities manipulation. Journal of Accounting and Economics 42(3):335-370.

Salvato, C., and K. Moores. 2010. Research on accounting in family firms: past accomplishments and future challenges. Family Business Review 23(3):193-215.

Schipper, K. 1989. Commentary on earnings management. Accounting Horizons 3(4):91-102.

Shivakumar, L. 2013. The role of financial reporting in debt contracting and in stewardship. Accounting and Business Research 43(4):362-383.

Simon, H. 1996. Hidden champions. Lessons from 500 of the world's best unknown companies. Boston: Harvard Business School Press.

Singleton-Green, B. 2016. SME accounting requirements: Basing policy on evidence. ICAEW Public Policy Paper. London: Institute of Chartered Accountants in England and Wales.

Sirmon, D.G., and M.A. Hitt. 2003. Managing resources: linking unique resources, management and wealth in family firms. Entrepreneurship Theory and Practice 27(4):339-358.

Stewart, A., and M.A. Hitt. 2012. Why can't a family business be more like a nonfamily business? Modes of professionalization in family firms. Family Business Review 25(1):58-86.

Stiftung Familienunternehmen. 2019. Die volkswirtschaftliche Bedeutung der Familienunternehmen [The economic relevance of family firms]. Mannheim: Stiftung Familienunternehmen.

Stockmans, A., N. Lybaert, and W. Voordeckers. 2010. Socioemotional wealth and earnings management in private family firms. Family Business Review 23:280-294.

Tanski, J.S. 2006. Bilanzpolitik und Bilanzanalyse nach IFRS. München: Vahlen.

Tong, Y. 2008. Financial reporting practices of family firms. Advances in Accounting 23:231-261. 
Vanstraelen, A., and C. Schelleman. 2017. Auditing private companies: what do we know? Accounting and Business Research 47(5):565-584.

Villalonga, B., and R. Amit. 2006. How do family ownership, control and management affect firm value? Journal of Financial Economics 80:385-417.

Wagenhofer, A. 2006. Management accounting research in German-speaking countries. Journal of Management Accounting Research 18:1-19.

Wang, D. 2006. Founding family ownership and earnings quality. Journal of Accounting Research 44:619-656.

Weißenberger, B.E., and H. Angelkort. 2011. Integration of financial and management accounting systems: the mediating influence of a consistent financial language on controllership effectiveness. Management Accounting Research 22(3):160-180.

Weißenberger, B.E., H. Angelkort, and C. Kleine. 2011. Business Reporting für Kapitalmärkte als Treiber einer integrierten Rechnungslegung? Empirische Evidenz aus deutschen Großunternehmen. Der Betrieb 64(39):2157-2161.

Zellweger, T.M., K.A. Eddleston, and F.W. Kellermanns. 2010. Exploring the concept of familiness: Introducing family firm identity. Journal of Family Business Strategy 1:54-63.

Zellweger, T.M., R.S. Nason, M. Nordqvist, and C.G. Brush. 2011. Why do family firms strive for non-financial goals? an organizational identity perspective. Entrepreneurship Theory and Practice 37:222-249.

Publisher's Note Springer Nature remains neutral with regard to jurisdictional claims in published maps and institutional affiliations. 